\title{
The new concept of univentricular heart
}

\section{Carla Frescura and Gaetano Thiene* \\ Cardiovascular Pathology, Department of Cardiac Thoracic and Vascular Sciences, University of Padua Medical School, Padua, Italy}

\section{Edited by:}

Antonio Francesco Corno, University Sains Malaysia, Malaysia

Reviewed by:

Robert Joseph Dabal, University of Alabama at Birmingham, USA

Robert Henry Anderson, Newcastle University, UK

*Correspondence:

Gaetano Thiene, Cardiovascular Pathology, Department of Cardiac Thoracic and Vascular Sciences, University of Padua Medical School, Istituto di Anatomia Patologica, Via A

Gabelli 61, Padova 35121, Italy

e-mail: gaetano.thiene@unipd.it
The concept of univentricular heart moved from hearts with only one ventricle connected with atria [double inlet ventricle or absent atrioventricular (AV) connection] to hearts not amenable to biventricular repair, namely hearts with two ventricles unable to sustain separately pulmonary and systemic circulations in sequence. In the latter definition, even hearts with one hypoplastic ventricle are considered "functional" univentricular hearts. They include pulmonary/aortic atresia or severe stenosis with hypoplastic ventricle, and rare conditions like huge intramural cardiac tumors and Ebstein anomaly with extreme atrialization of right ventricular cavity. In this setting, the surgical repair is univentricular with "Fontan" operation, bypassing the ventricular mass. In other words, functionally univentricular heart is a condition in which, after surgery, only one ventricle sustain systemic circulation. Univentricular hearts (double inlet or absent AV connection) almost invariably show two ventricular chambers, one main and one accessory, which lacks an inlet portion. The latter is located posteriorly when morphologically left and anteriorly when morphologically right. As far as double inlet left ventricle, this is usually associated with discordant ventriculo-arterial (VA) connection (transposition of the great arteries) and all the blood flow to the aorta, which takes origin from the hypoplastic anterior right ventricle, is ventricular septal defect (bulbo-ventricular foramen) dependent. If restrictive, an aortic arch obstruction may be present. Double inlet left ventricle may be rarely associated with VA concordance (Holmes heart). As far as double inlet right ventricle with posterior hypoplastic left ventricular cavity, ventriculo-arterial connection is usually of double outlet type; thus the term double inlet-outlet right ventricle may be coined. Absent right or left AV connection may develop in the setting of both D- or L-loop, whatever the situs. In this condition, the contra-lateral patent $\mathrm{AV}$ valve may be either mitral or tricuspid in terms of morphology and the underlying ventricle (main chamber) either morphologically left or right. Establishing the loop, whatever right or left (also called right or left ventricular topology), is a fundamental step in the segmental-sequential analysis of congenital heart disease.

Keywords: aortic atresia, double inlet ventricle, mitral atresia, pulmonary atresia, single ventricle, tricuspid atresia univentricular heart

\section{INTRODUCTION}

The segmental, sequential approach used for the analysis and categorization of the heart's malformations has indubitably improved the diagnosis and classification of complex congenital heart disease (CHD).

De la Cruz (1) and Van Praagh (2-4) first emphasized the advantage to consider the malformed hearts in terms of atrial, ventricular, and arterial components, however to our mind, the merit of systematic categorization and clinical application has to be assigned to the English School of Anderson and co-workers (5-11).

While approaching the diagnosis of any CHD, you should consider the heart as a three floor building. The atria are the platform, the ventricles the first floor, and the great arteries the second floor, connected each other through valve orifices and divided by septa (Figure 1) (12, 13).

The three segments are separated by two junctions, named atrioventricular (AV) and ventriculo-arterial (VA). The first connects each atrium with the corresponding ventricle and the second connects each ventricle with the appropriate artery. Normally, each junction possesses two distinct valves: mitral and tricuspid valves at $\mathrm{AV}$ and pulmonary and aortic valves in the VA junctions.

The AV connection is biventricular when each atrium connects separately with one ventricle. The biventricular AV connection is concordant when the right atrium connects with the right ventricle and the left atrium connects with the left ventricle, discordant when the right atrium connects with the left ventricle and the left atrium connects with the right ventricle, whatever be the situs, either solitus or inversus. In the setting of isomerism of right and left appendages, the AV connection cannot be defined as concordant or discordant but biventricular and the topology of the ventricles ( $\mathrm{D}$ or L-loop) should be added.

In the presence of biventricular $\mathrm{AV}$ connection, the right and left ventricles are of normal morphology and good size, each being constituted by inlet, outlet, and apico-trabecular components. The presence of two separated valves or of a common AV valve does not change the basic connection, whether concordant or discordant.

Univentricular connection is present when the atria are connected predominantly with one ventricular chamber due to 


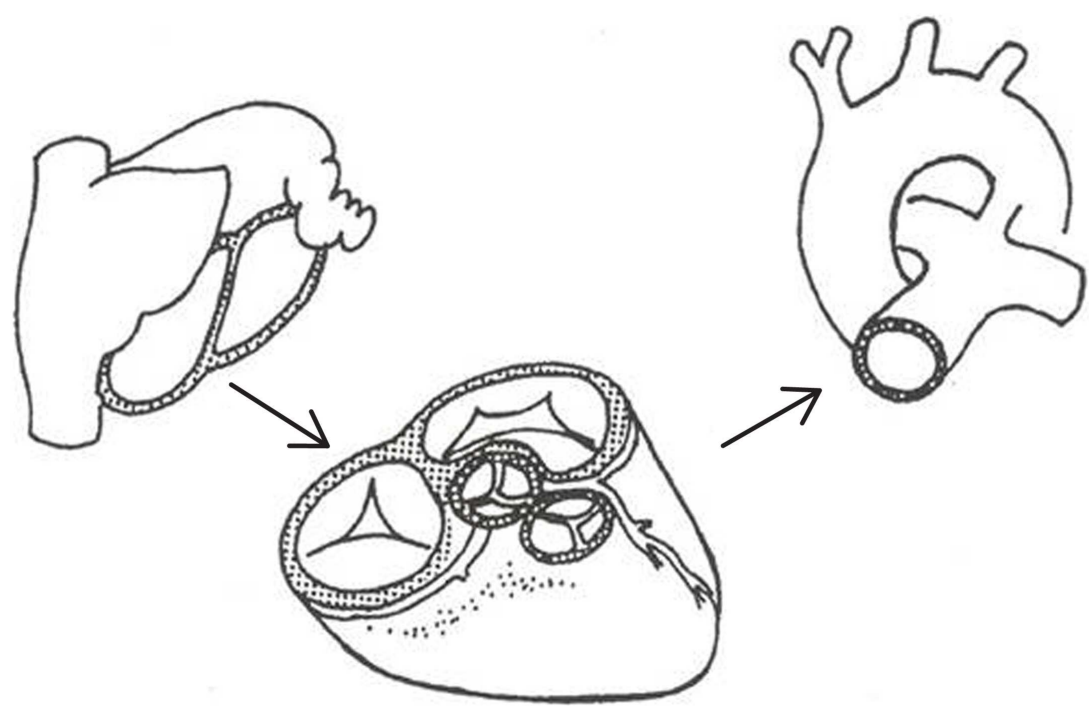

FIGURE 1 | Segmental analysis of congenital heart disease. The normal heart consists of three segments: atria, ventricles, and the great arteries connected each other at atrioventricular and ventriculo-arterial junctions [partially modified from Refs. (12, 13)].

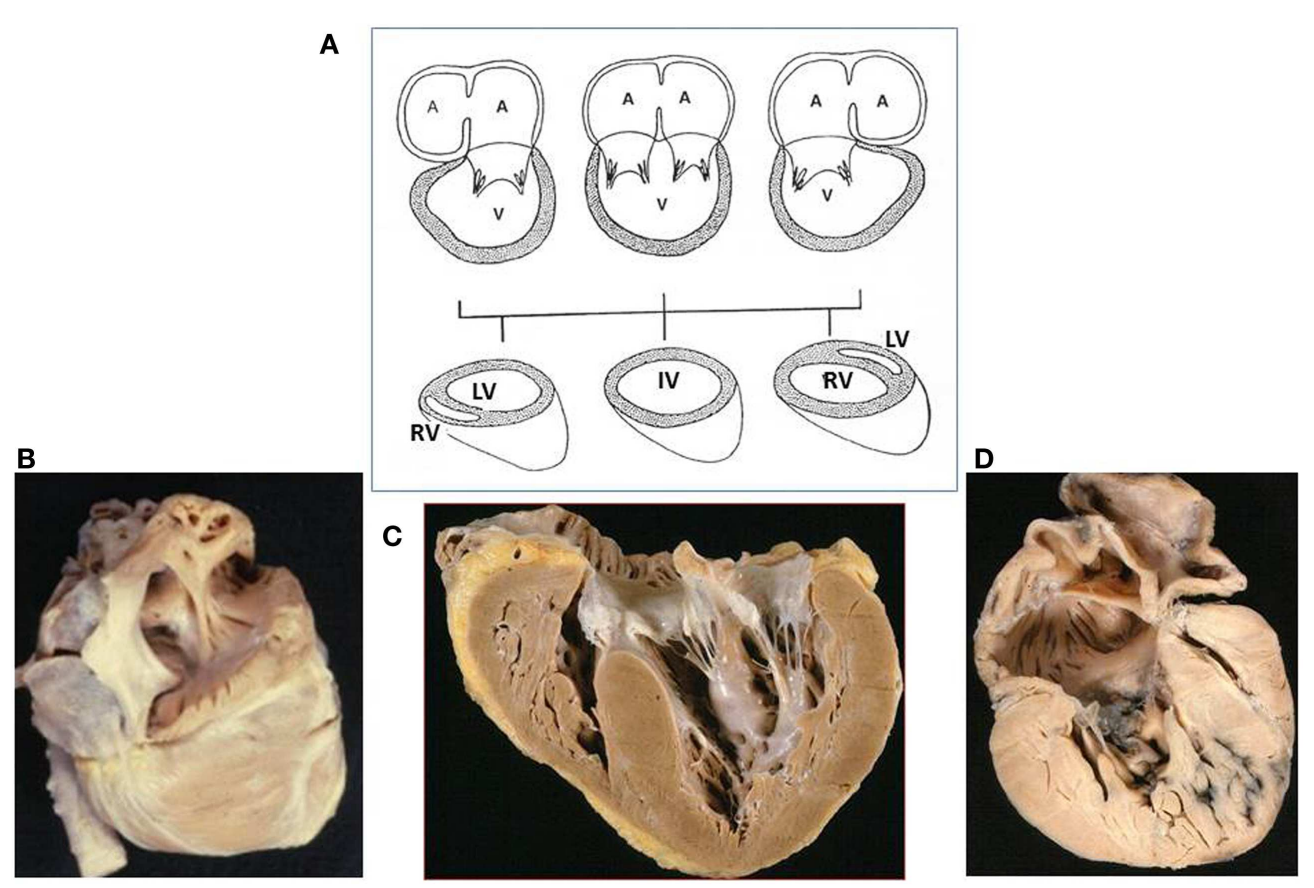

FIGURE 2 | Univentricular atrioventricular connection. (A) The

atrioventricular connection is univentricular when both atria drain mostly into a single ventricular chamber through two patent or a common atrioventricular valves (double inlet connection) or through a single valve in case of absent right or left connection. Note the anterior position of the right ventricle and the posterior position of the left ventricle when the main chamber is of left or right morphology, respectively. In the absence of ventricular septum, the main ventricular chamber is of indeterminate morphology (IV). (B). Absent right atrioventricular connection (tricuspid atresia), viewed from the right atrium: no orifice is present at the right atrial floor. (C) Double inlet ventricle: two separate valves drain into a main ventricular chamber of left morphology: note the hypoplastic right ventricle. The right atrioventricular valve is overriding the interventricular septum. (D) Absent left atrioventricular connection (mitral atresia): no orifice is present at the left atrial floor and the left ventricle is slit-like. $A$, atrium; IV, indeterminate ventricle; $L V$, left ventricle; $R V$, right ventricle; $V$, ventricle. [partially modified from Ref. (12)] absence of one $\mathrm{AV}$ valve (absent connection) or to the presence of two valves or of a common valve predominately draining in one ventricle (double inlet connection) (Figure 2). In both conditions, one ventricle is of good size and the other is hypoplastic, missing the inlet portion, and the two ventricular cavities are separated by an interventricular septum. 
The main ventricular chamber may be of right or left morphology or, in exceptional cases, indeterminate, which means that the ventricular septum failed to develop. Establishing the type of ventricular loop is a fundamental step since an absent AV connection may occur with discordant loop (L-loop in situs solitus, D-loop in situs inversus) so that the morphology of the main ventricular chamber may be right or left, respectively.

It should be underlined that, when an even tiny ventricular septum is recognizable, a second hypoplastic ventricular chamber is almost always existing and it is of right morphology, anteriorly located, when the main ventricular chamber is of left morphology, and it is posteriorly located and of left morphology when the mean ventricular chamber is of right morphology.

At the VA junction, the connection is concordant when the aorta takes origin from the left ventricle and the pulmonary artery from the right ventricle, or discordant when the aorta takes origin of the right ventricle and the pulmonary artery from the left ventricle. Double outlet VA connection is observed when more than one and half of the great arteries origin from a ventricle. The condition when only one patent great artery takes origin from the heart is called single outlet: single aortic outlet with pulmonary atresia, single pulmonary outlet with aortic atresia or single outlet with truncus arteriosus. Aortic atresia and pulmonary atresia with intact septum are usually characterized by the presence of one large main ventricle and of a hypoplastic accessory ventricle. In these cases, the AV connections are usually concordant and the ventricles have an inlet. However, aortic atresia can be associated with mitral atresia with severe hypoplastic left heart and absent inlet (absent left $\mathrm{AV}$ connection with single pulmonary outlet). Absent right $\mathrm{AV}$ connection with single aortic outlet, namely tricuspid-pulmonary atresia, is almost non-existing.

The hearts characterized by one large and one hypoplastic ventricular chamber are usually the consequence of univentricular AV connection (double inlet or absent AV connection) and are usually known as univentricular hearts.

But there are also hearts, with regular AV and VA connections presenting both inlet and outlet portions, in which one ventricle is unable to sustain the pulmonary or the systemic circulation. That is the case of hearts with hypoplastic left ventricle due to aortic stenosis/atresia or with hypoplastic right ventricle due to pulmonary stenosis/atresia or those with Ebstein anomaly and large atrialization of the right ventricular cavity.

Under the term "functionally univentricular heart," Anderson and co-workers (14-18) unified different anatomical malformations characterized by the fact that one of the two ventricles is unable to sustain the pulmonary or the systemic circulation as a consequence of diminutive size or deficiency function. In these cases, the ventricles are not amenable for biventricular repair and only one ventricle or one and half ventricular repair is possible.

We reviewed our Anatomical Collection of CHD with the aim to identify the anatomical characteristics of the hearts corresponding to the new definition of functionally univentricular heart.

\section{MATERIAL AND METHODS}

In the Anatomical Collection of the University of Padua, consisting in 1612 hearts with CHD, we identified the hearts corresponding to the definition of functionally univentricular heart.
Of each heart, we described the atrial situs, the AV, and VA connections, in terms of type and mode, the morphology of the ventricles and the associated anomalies.

On the base of the presence and morphology of the interventricular septum, each ventricle is reported as having right, left, or indeterminate morphology and on the base of dimensions as dominant or hypoplastic. The topology of the ventricles was identified as D- or L-loop: D-loop corresponding to morphologically right ventricle in right anterior position and morphologically left ventricle in left posterior position and L-loop with morphologically right ventricle in left anterior position and morphologically left ventricle in right posterior position. Mode of connection was used to identify the presence of two patent valves, common valve, imperforate valve, straddling, or overriding valves.

\section{RESULTS}

Two different groups of heart were identified with one large and one hypoplastic ventricles:

Hearts with univentricular AV connection:

- Double inlet left, right, or indeterminate ventricle,

- Absent left or right connection.

Hearts with biventricular AV connection and single VA connection:

- Aortic atresia with intact ventricular septum (IVS) and hypoplastic left ventricle;

- Pulmonary atresia with IVS and hypoplastic right ventricle.

\section{HEARTS WITH UNIVENTRICULAR AV CONNECTION}

Univentricular AV connection was present in 196 (12\%) cases. Fifty-five hearts showed a double inlet connection and 141 an absent AV connection (Table 1).

The situs was solitus in 171 cases. Right isomerism was present in 18 and left isomerism in 7 . No case of situs inversus was found (Table 1).

\section{DOUBLE INLET VENTRICLE}

Among the 55 hearts with double inlet connection, the left ventricle was the dominant ventricle in 35 cases and the right ventricle was the dominant ventricle in 19 cases (Table 1). In one case, only one ventricular chamber with indeterminate morphology was present (Table 1).

\section{DOUBLE INLET LEFT VENTRICLE}

The atrial situs was solitus in 29 cases and a right atrial isomerism was present in 6 . No case of double inlet left ventricle was found in association with situs inversus or left atrial isomerism (Table 1).

\section{Hearts with situs solitus: $\mathbf{2 9}$ cases}

The dominant ventricle showed a left ventricular morphology and the hypoplastic ventricle of right morphology was located antero superiorly and to the right (D-loop) in 23 and on the left ( $\mathrm{L}-\mathrm{loop}$ ) in 6 hearts. 
Table 1 | Univentricular AV connection: atrial situs

\begin{tabular}{|c|c|c|c|c|c|}
\hline \multirow[t]{2}{*}{ Atrial situs } & \multicolumn{3}{|c|}{ Double inlet ventricles: 55 hearts } & \multicolumn{2}{|c|}{ Absent AV connection: 141 hearts } \\
\hline & Double inlet LV & Double inlet RV & Double inlet IV & Absent left connection & Absent right connection \\
\hline Solitus & 29 & 5 & 1 & 108 & 28 \\
\hline Right isomerism & 6 & 12 & - & - & - \\
\hline Left isomerism & - & 2 & - & 2 & 3 \\
\hline Total & 35 & 19 & 1 & 110 & 31 \\
\hline
\end{tabular}

$A V$, atrioventricular; $I V$, indeterminate ventricle; $L V$, left ventricle; $R V$, right ventricle.

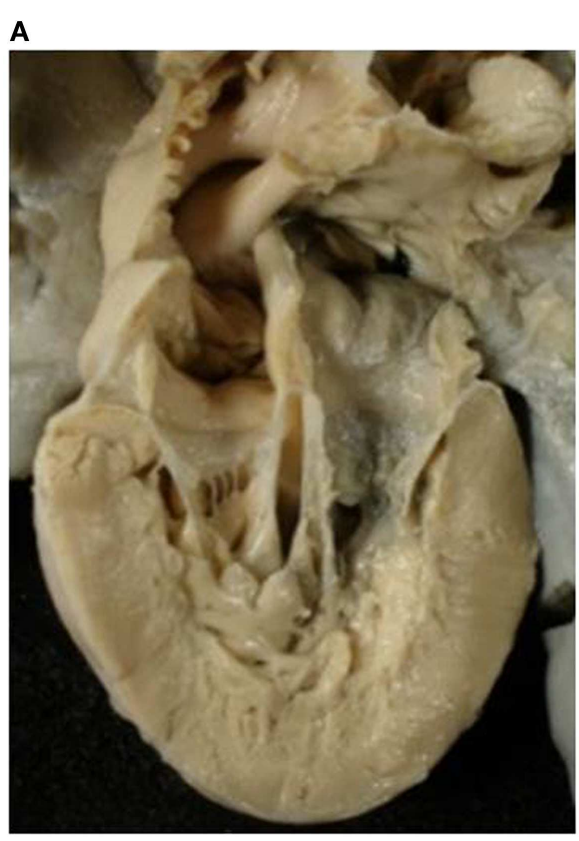

FIGURE 3 | Double inlet left ventricle. (A) Both the AV valves drain into a posterior ventricular chamber of left morphology. (B) External view of the heart: the hypoplastic right ventricle is located in antero-superior position and

Two separate valves (Figures $\mathbf{2 C}$ and $\mathbf{3}$ ) were present in 27 cases. An imperforate valve was noted in two cases: right in one and left in one. The right AV valve was straddling in 7 cases and overriding in one (Table 2 ).

The VA connections were concordant in 4 cases (Holmes heart) (Figure 4), discordant in 23 (Figure 3), and double outlet left ventricle in 1 . Single aortic outlet (pulmonary atresia) was present in 1 case, with the aorta originating from the right ventricle (Table 3 ). In 3 cases an imperforate pulmonary valve was observed, 1 with concordant and 2 with discordant VA connections.

The associated anomalies are described in Table 4.

\section{Hearts with right isomerism: six cases}

Six cases presented with right isomerism in association with the absence of the spleen and visceral heterotaxy (Table 1).

A common AV valve was present in all cases (Table 2).

The VA connections were discordant in one case and double outlet from left ventricle in one. A single aortic outlet (pulmonary

\section{B}

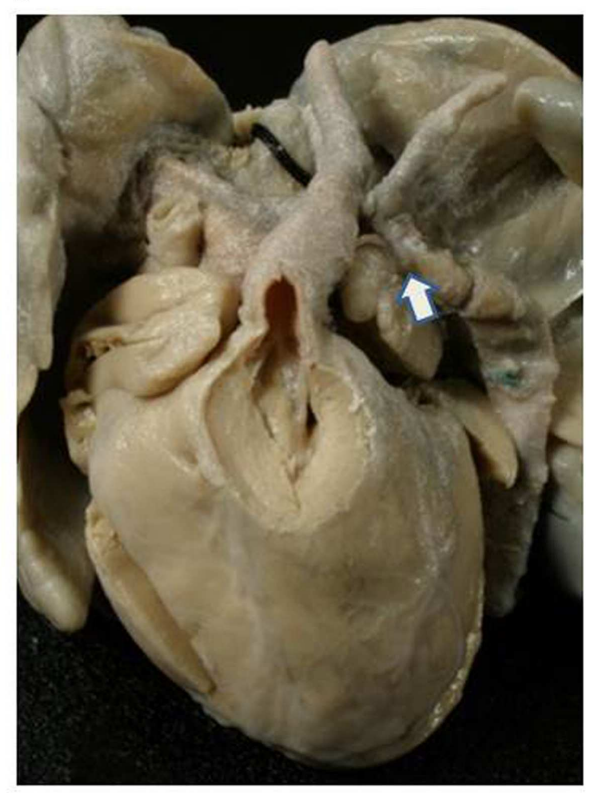

gives origin to the aorta (discordant ventriculo-arterial connection). Note the restrictive ventricular septal defect (bulbo-ventricular foramen). The arrow indicates the surgical repair of the aortic arch obstruction.

atresia) was present in four cases with aorta originating from the right ventricle (Table 3 ).

The ventricular topology was D-loop in four and L-loop in two hearts (Table 4).

Associated anomalies are described in Table 4.

\section{DOUBLE INLET RIGHT VENTRICLE}

Among the 19 hearts with double inlet right ventricle, the atrial situs was solitus in 5 cases, right isomerism in 12, and left isomerism in 2 (Table $\mathbf{1}$ ).

\section{Hearts with situs solitus: five cases}

In these hearts, the dominant ventricle showed a right ventricular morphology with coarse apical trabeculations (Figures 5 and 6). The hypoplastic left ventricle was found in postero-inferior position on the left in four cases (D-loop) and on the right in one (L-loop) (Table 4).

Two separate valves were present in two cases (Figure 5) and a common AV valve in three (Figure 6) (Table 2). 
Table 2 | Double inlet ventricle: mode of AV connection

\begin{tabular}{|c|c|c|c|c|c|c|}
\hline Mode of AV connection & \multicolumn{2}{|c|}{ Double inlet LV 35 hearts } & \multicolumn{3}{|c|}{ Double inlet RV 19 hearts } & $\begin{array}{c}\text { Double inlet IV } 1 \text { hear } \\
\text { Situs } \\
\text { solitus } \\
1\end{array}$ \\
\hline Two patent valves & 27 & - & 2 & 1 & - & 1 \\
\hline Common valve & - & 6 & 3 & 11 & 2 & - \\
\hline Imperforate left valve & 1 & - & - & - & - & - \\
\hline
\end{tabular}

$A V$, atrioventricular; $I V$, indeterminate ventricle; $L V$, left ventricle; $R V$, right ventricle.
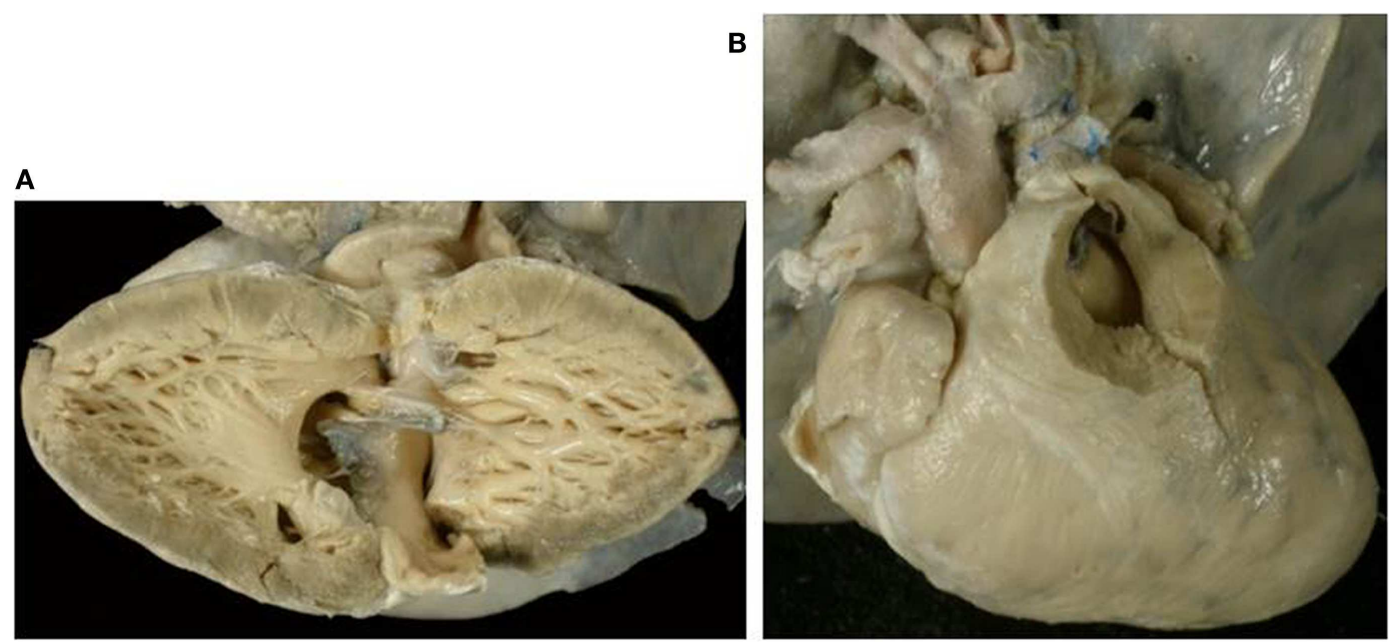

FIGURE 4 | Double inlet left ventricle with concordant ventriculoarterial connection (Holmes heart). (A) View of the dominant left ventricle in which both the atria mostly drain through two patent $\mathrm{AV}$ valves.

(B) External view of the heart with hypoplastic right ventricle and normally related great arteries. The aorta takes origin from the posterior ventricular chamber of left morphology and the pulmonary artery from the anterior hypoplastic ventricle of right morphology (concordant ventriculo-arterial connection).

Table 3 | Double inlet ventricles: type of VA connection.

\section{Type of VA connection}

\section{Double inlet LV 36 hearts}

\begin{tabular}{cc}
\hline Situs & Right \\
solitus & isomerism
\end{tabular}

\section{Concordant}

Discordant

Double outlet RV

Double outlet LV

Double outlet IV

Single Ao outlet from RV (Po atresia)

Single Po outlet from RV (Ao atresia)
29

6

$\begin{array}{rrr}4 & - & 2 \\ 23 & 1 & - \\ - & - & 1 \\ 1 & 1 & - \\ - & - & - \\ 1 & 4 & 2 \\ - & - & -\end{array}$

Double inlet RV 19 hearts

\begin{tabular}{lcc}
\hline Situs & Right & Left \\
solitus & isomerism & isomerism
\end{tabular}

2

$-$

1

$-$

$-$

2
12

-
-
7
-
-
4
1

2

-
-
1
-
-
-
1

Double inlet IV 1 heart

\section{Situs}

solitus

1

-
-
-
-
1
-
-

Ao, aortic; $I V$, indeterminate ventricle; $L V$, left ventricle; $R V$, right ventricle; $P o$, pulmonary; $V A$, ventriculo-arterial. 
Table 4 | Double inlet ventricle: associated anomalies.

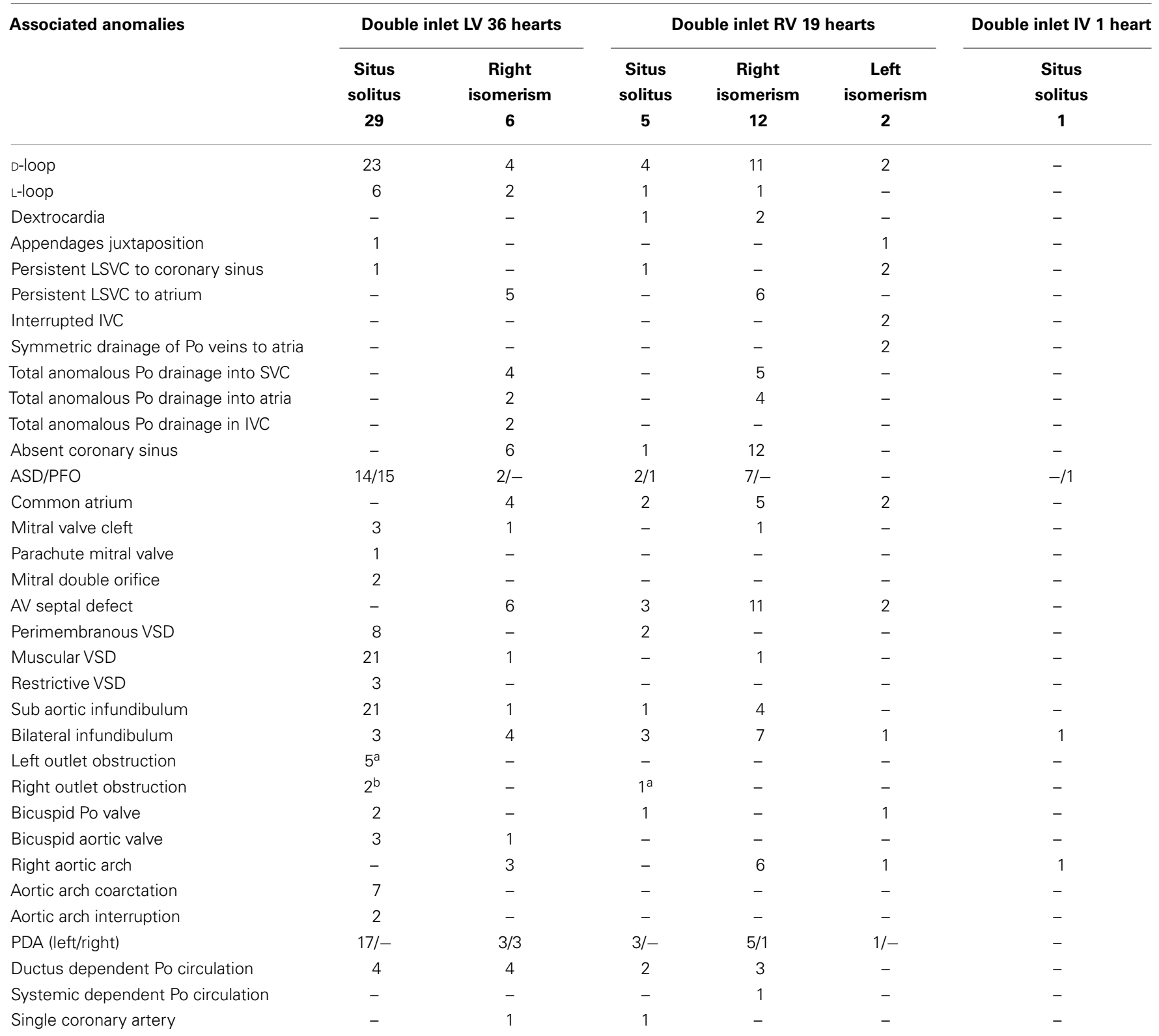

$A S D$, atrial septal defect; $A V$, atrioventricular; $I V$, indeterminate ventricle; IVC, inferior vena cava; $L S V C$, left superior vena cava; $L V$, left ventricle; PDA, patent ductus arteriosus; PFO, patent foramen ovalis; Po, pulmonary; $R V$, right ventricle.

a Fibrous diaphragm.

${ }^{b}$ Hypertrophy of septal bands.

The VA connections were concordant in two cases, double outlet right in one (Figure 6) and single aortic outlet (pulmonary atresia) from the right ventricle in two (Table 3 ).

The associated anomalies are reported in Table 4.

\section{Hearts with right isomerism: 12 cases}

In the 12 cases with right isomerism, a common $\mathrm{AV}$ valve was present in 11 cases and two separated valves in 1 (Table 2).
The VA connections were double outlet right ventricle in seven, single aortic outlet (pulmonary atresia) from the right ventricle in four, and single pulmonary outlet (aortic atresia) from the right ventricle in one (Table 3 ).

The left ventricle was hypoplastic in all cases and located in left posterior position in 11 cases (D-loop) and on the right posterior position ( $\mathrm{L}$-loop) in 1 case (Table 4).

In all cases the spleen was absent with visceral heterotaxy and presence of bilateral bronchi and lungs of right morphology. 
A

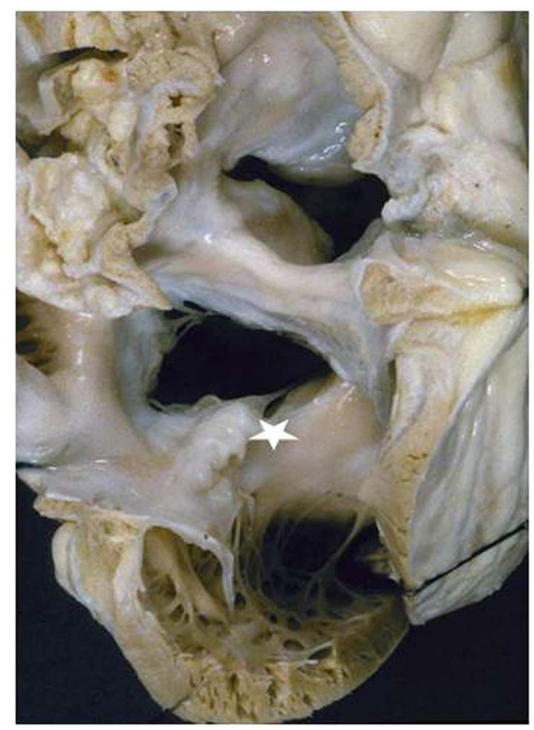

B

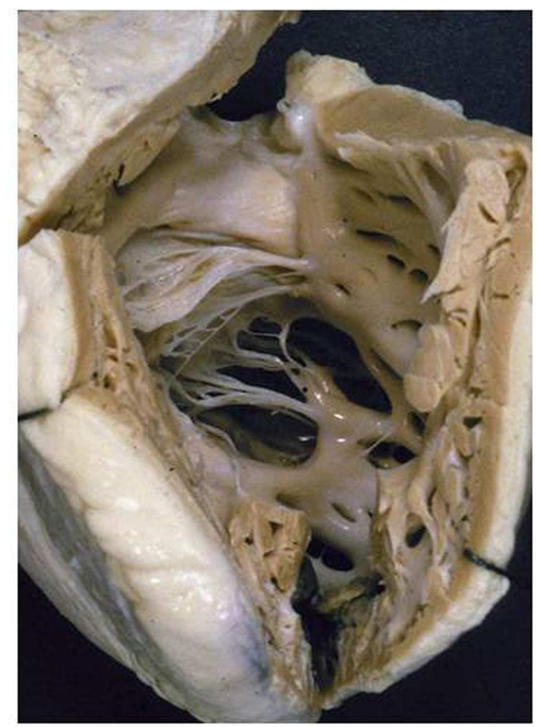

FIGURE 5 | Double inlet-outlet right ventricle. (A) View from the atria: both the atria drain mostly into a main ventricular chamber of right morphology through two separate atrioventricular valves. The left atrioventricular valve straddles and overrides the interventricular septum (star): note the posterior small ventricular chamber of left morphology. (B) View of the large right ventricle with coarse trabeculations in which both the atrioventricular valves drain.
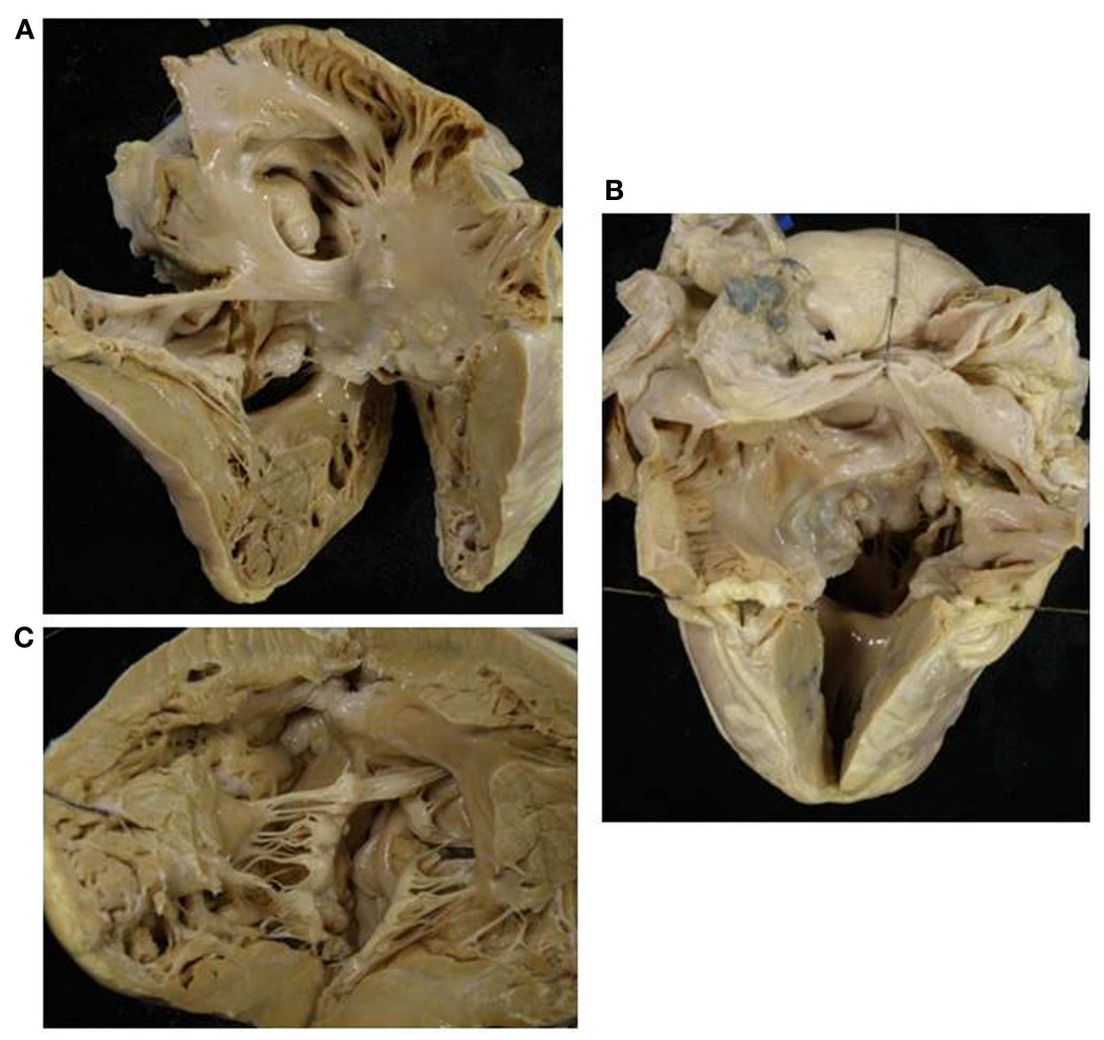

FIGURE 6 | Double inlet-outlet right ventricle. (A) View of the right-sided cardiac chambers: a common atrioventricular valve is present and drains the blood from both atria, predominantly into an anterior ventricular chamber of right morphology. (B) View of the left-sided cardiac chambers: note the hypoplasia of the posterior left ventricle. (C) From the right ventricle both the aorta and the pulmonary artery take origin. The pulmonary outlet is stenotic. Note the common atrioventricular valve mostly connected to the right ventricle. 


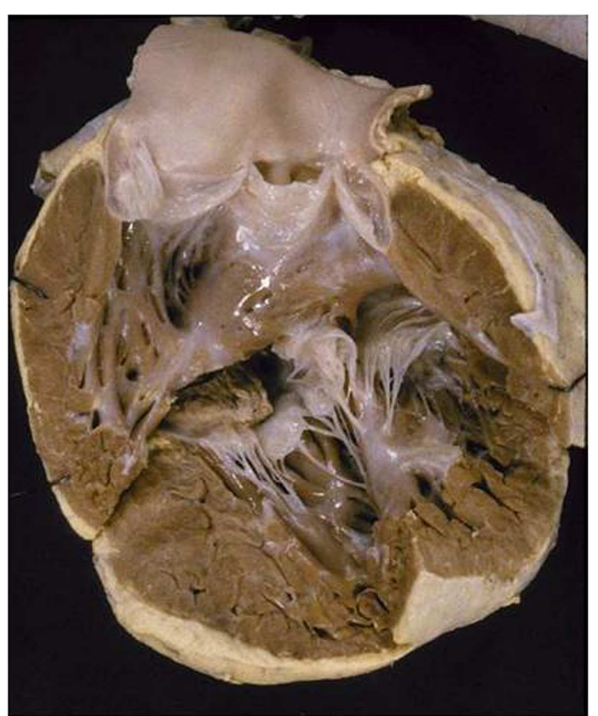

FIGURE 7 | Double inlet indeterminate ventricle. Both the atrioventricular valves drain into a ventricular chamber with coarse trabeculations of indeterminate morphology. A second separate ventricle was not identified.

The associated anomalies are described in Table 4.

\section{Hearts with left isomerism: two cases}

In both cases with left isomerism, a common AV valve was present (Table 2). The VA connections were double outlet right ventricle in one case and single pulmonary outlet (aortic atresia) from the right ventricle in one (Table 3 ).

The ventricular topology was D-loop in all cases (Table 4).

Common atrium, persistent left SVC, interruption of IVC with azygos continuation in right SVC and symmetric drainage of the pulmonary veins were present in both (Table 4).

\section{DOUBLE INLET INDETERMINATE VENTRICLE}

In this rare variant of double inlet ventricle, only a solitary chamber was found within the ventricular mass with coarse apical trabeculations (Figure 7). The existence of associated rudimentary ventricle was accurately excluded.

Two separate valves were present (Table 2) and the VA connections were double outlet from the indeterminate ventricular chamber (Table 3). A patent foramen ovalis was present at atrial level and bilateral infundibulum and a right aortic arch were also noted (Table 4).

\section{HEARTS WITH ABSENT AV CONNECTION}

One hundred ten cases with absent left AV connection and 31 cases with absent right AV connection were found in our Anatomical Collection. The absent connection not always corresponded to mitral or tricuspid atresia because in some cases the development of L-ventricular loop placed the left ventricle on the right and the right ventricle on the left, so that the patent valve could be a mitral valve on the right and the tricuspid valve on the left.

\section{ABSENT LEFT AV CONNECTION}

One hundred eight hearts, characterized by the absence of the left AV valve, presented with situs solitus and only two with left isomerism (Table 1). In no case, absence of the left AV valve was found in association with situs inversus or right isomerism.

\section{Hearts with situs solitus: 108 cases}

A regular D-ventricular loop was observed in 98 cases with leftsided hypoplastic left ventricle (Figures 2D and 8). In the 10 cases with L-ventricular loop and absent left AV connection the right-sided patent valve was the mitral and the hypoplastic ventricle was the right one.

Hearts with D-loop: 98 cases with dominant ventricle with right ventricular morphology ("mitral atresia"). The left AV valve was absent in 92 cases and imperforated in 5. A common AV valve was present in 1 case (Table 5). Among the cases with absent left AV valve, the tricuspid valve was straddling in 2 .

In 62 cases, a single pulmonary outlet (aortic atresia) with pulmonary artery originating from the right ventricle was present (Table 6). In the remaining, the VA connections were concordant in 11, discordant in 2 (Figure 8), double outlet from right ventricle in 19 , and single aortic outlet (pulmonary atresia) with aorta originating from the right ventricle in 4 hearts (Table 6).

The left ventricle was hypoplastic in all cases and slit-like in cases with associated aortic atresia. Fibroelastosis of the diminutive left ventricle was noted in two cases.

Detailed description of associated anomalies is reported in Table 7.

Hearts with L-loop: 10 cases with dominant ventricle with left ventricular morphology ("tricuspid atresia"). In all cases, the left $\mathrm{AV}$ valve was absent and the patent right $\mathrm{AV}$ valve was mitral in morphology. In one case, the right AV valve was straddling (Table 5).

The VA connections were concordant in one, discordant in six, double outlet from left ventricle in two, and single aortic outlet (pulmonary atresia) from right ventricle in one (Table 6).

Associated anomalies are found in Table 7.

\section{Hearts with left isomerism: two cases}

In both cases atria and lungs showed a bilateral left morphology (both left atrial appendages, lungs with two lobes and lingula), abdominal visceral heterotaxy, and multiple spleens.

A D-ventricular loop was noted in 1 case and L-loop in the other.

In the heart with dominant ventricle with right ventricular morphology (D-loop), the patent AV valve was the tricuspid valve ("mitral atresia") and the VA connection was single aortic outlet (pulmonary atresia) from the right ventricle associated to dextrocardia (Tables 6 and 7).

In the heart, dominant ventricle with left ventricular morphology (L-loop) the patent AV valve was the mitral valve ("tricuspid atresia"). In this case, the VA connection was discordant and dextrocardia was present (Tables 6 and 7).

Associated anomalies in Table 7. 

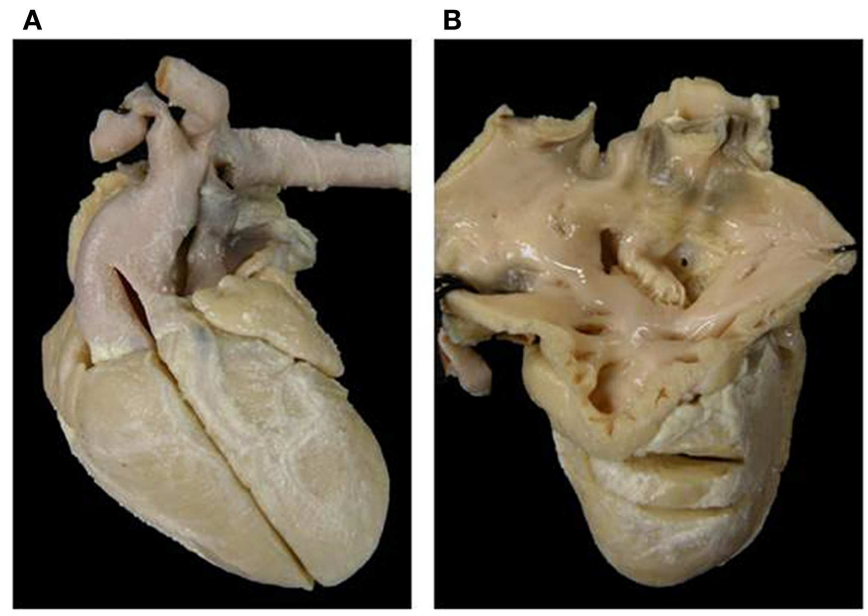

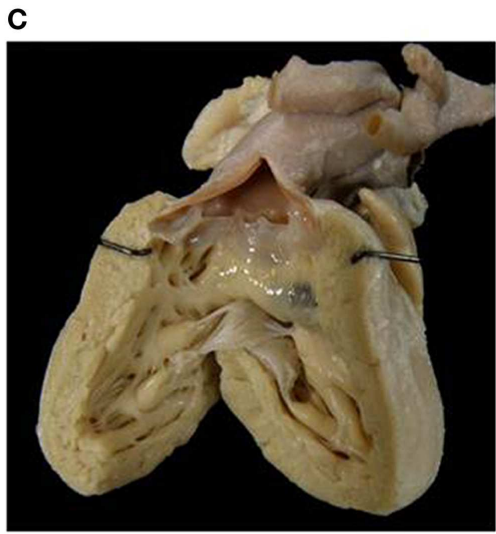

FIGURE 8 | Absent left atrioventricular connection (mitral atresia) with discordant ventriculo-arterial connection. (A) External view of the heart with the aorta in right anterior position and the pulmonary artery in left posterior position. (B) At the floor of the left atrium, there is no orifice labsent left atrioventricular connection). (C) A good sized, right-sided, morphologically right ventricle (D-loop) is present from which the aorta takes origin (discordant ventriculo-arterial connection). The pulmonary artery takes origin from the left ventricle (not shown).

Table 5 | Absent AV connections: mode of AV connection.

\begin{tabular}{|c|c|c|c|c|c|c|c|}
\hline \multirow[t]{3}{*}{ Mode of AV connection } & \multicolumn{4}{|c|}{ Absent left AV connection 110 hearts } & \multicolumn{3}{|c|}{ Absent right $\mathrm{AV}$ connection 31 hearts } \\
\hline & \multicolumn{2}{|c|}{ Situs solitus 108 hearts } & \multicolumn{2}{|c|}{ Left isomerism 2 hearts } & \multicolumn{2}{|c|}{ Situs solitus 30 hearts } & \multirow{2}{*}{$\begin{array}{c}\text { Left isomerism } 1 \text { heart } \\
\text { L-loop } 1\end{array}$} \\
\hline & D-loop 98 & L-Ioop 10 & D-loop 1 & L-loop 1 & D-loop 27 & L-loop 3 & \\
\hline Absent left valve & 92 & 10 & 1 & 1 & - & - & - \\
\hline Absent right valve & - & - & - & - & 26 & 3 & 1 \\
\hline Common valve & 1 & - & - & - & - & - & - \\
\hline Imperforate right valve & - & - & - & - & 1 & - & - \\
\hline Imperforate left valve & 5 & - & - & - & - & - & - \\
\hline
\end{tabular}

AV, atrioventricular.

\section{ABSENT RIGHT AV CONNECTION}

Thirty-one hearts with absent right AV connection were present in our Anatomical Collection (Figures 2A,B and 9-11). The atrial situs was solitus in 30 cases and a left isomerism was present in 1 case. No case of situs inversus or right isomerism was found (Table 1).

\section{Heart with situs solitus: $\mathbf{3 0}$ cases}

The relation of the ventricles was D-loop in 27 (Figure 9) and Lloop in 3 (Figure 11). In these latter cases, the patent left-sided AV valve was a tricuspid valve and the hypoplastic ventricle was the right-sided left ventricle.

Hearts with D-loop: 27 cases with dominant ventricle with left ventricular morphology (“tricuspid atresia"). Absent right AV valve was noted in 26 cases (Figures 2B, 9, and 10) and an imperforate right $\mathrm{AV}$ valve in 1 (Table 5).

The VA connections were concordant in 16 cases (Figure 9) and discordant in 5. A single aortic outlet (pulmonary atresia) was noted in 4 cases with the aorta originating from the right ventricle in 2 and from the left ventricle in 2. In all 4 cases with pulmonary atresia, the lungs were supplied by the ductus arteriosus. In 2 cases, a common arterial trunk was present (Figure 10) (Table 6).

The associated anomalies are reported in Table 7.

Hearts with L-loop: three cases with dominant ventricle with right morphology ("mitral atresia"). Absent right AV valve was noted in all cases (Figure 11) with straddling left AV valve in one case. The patent AV valve was tricuspid in morphology. The main chamber was of right morphology and the left ventricle was hypoplastic in all cases.

The VA connections were discordant in one, double outlet from right ventricle in one, and single aortic outlet (pulmonary atresia) from right ventricle in one (Figure 11) (Table 6).

Associated anomalies in Table 7.

\section{Hearts with left isomerism: one case}

In the single heart with left isomerism, a patent left-sided tricuspid valve was found at the AV junction ( $\mathrm{L}$-ventricular loop) and the VA connection was double outlet from right ventricle (Table 6). 
Table 6 | Absent AV connections: ventriculo-arterial connections

\begin{tabular}{|c|c|c|c|c|c|c|c|}
\hline \multirow[t]{2}{*}{ VA connections } & \multicolumn{4}{|c|}{ Absent left AV connection 110 hearts } & \multicolumn{3}{|c|}{ Absent right $\mathrm{AV}$ connection 31 hearts } \\
\hline & D-loop 98 & L-loop 10 & D-loop 1 & L-loop 1 & D-loop 27 & L-loop 3 & $\begin{array}{l}\text { Left isomerism } \\
\qquad 1 \text { heart } \\
\text { L-loop } 1\end{array}$ \\
\hline Concordant & 11 & 1 & - & - & 16 & - & - \\
\hline Double outlet LV & - & 2 & - & - & - & - & - \\
\hline Single Po outlet from RV (aortic atresia) & 62 & - & - & - & - & - & - \\
\hline Single Ao outlet from RV (pulmonary atresia) & 4 & 1 & 1 & - & 2 & 1 & - \\
\hline Single Ao outlet from LV (pulmonary atresia) & - & - & - & - & 2 & - & - \\
\hline Single outlet truncus arteriosus & - & - & - & - & 2 & - & - \\
\hline
\end{tabular}

Ao, aortic; $A V$, atrioventricular; $L V$, left ventricle; $P o$, pulmonary; $R V$, right ventricle; $V A$, ventriculo-arterial.

Table 7 | Absent AV connections: associated anomalies.

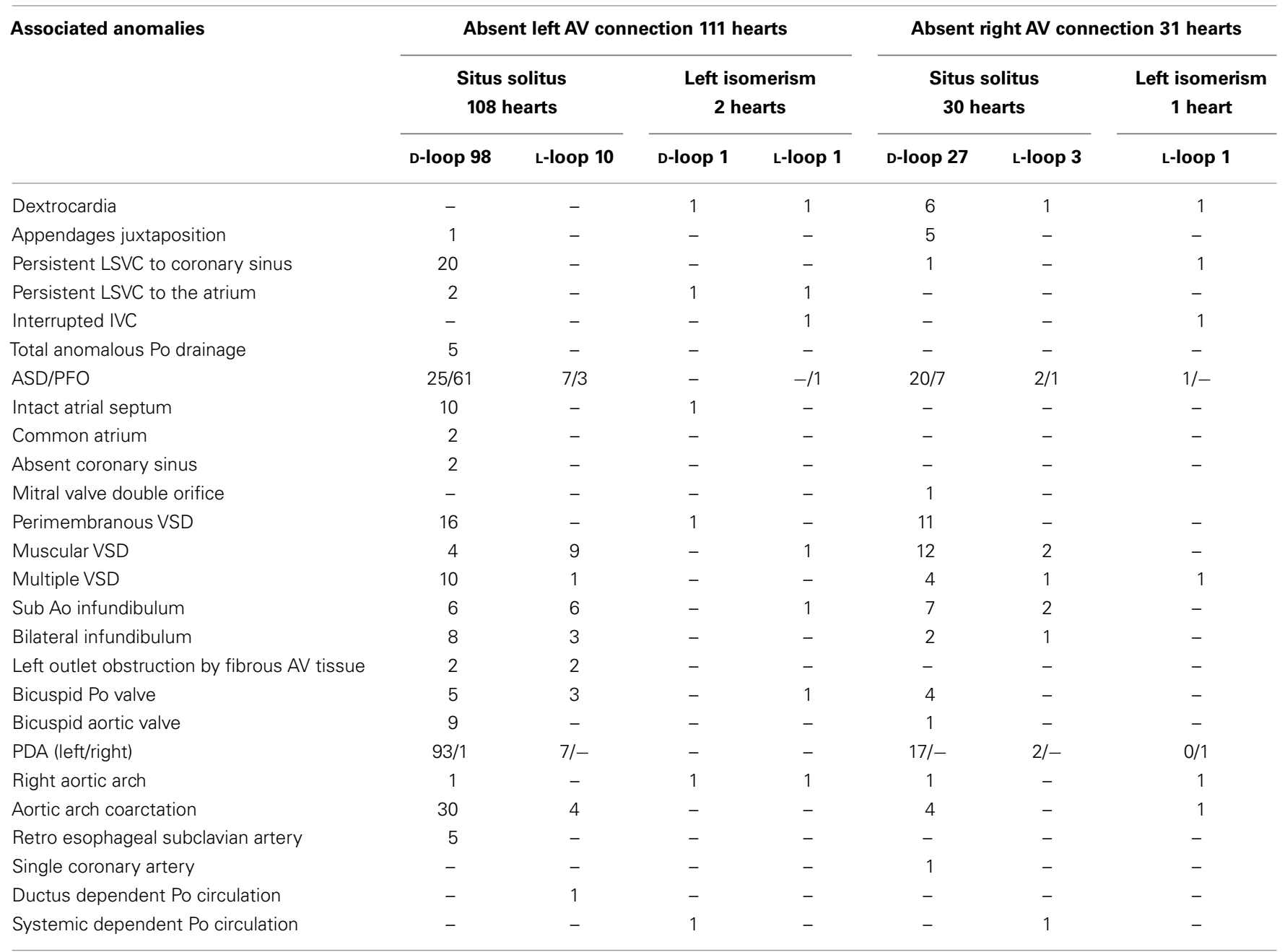

ASD, atrial septal defect; AV, atrioventricular; IVC, inferior vena cava; LSVC, left superior vena cava; PFO, patent foramen ovalis; PDA, patent ductus arteriosus; Po, pulmonary; VSD, ventricular septal defect. 

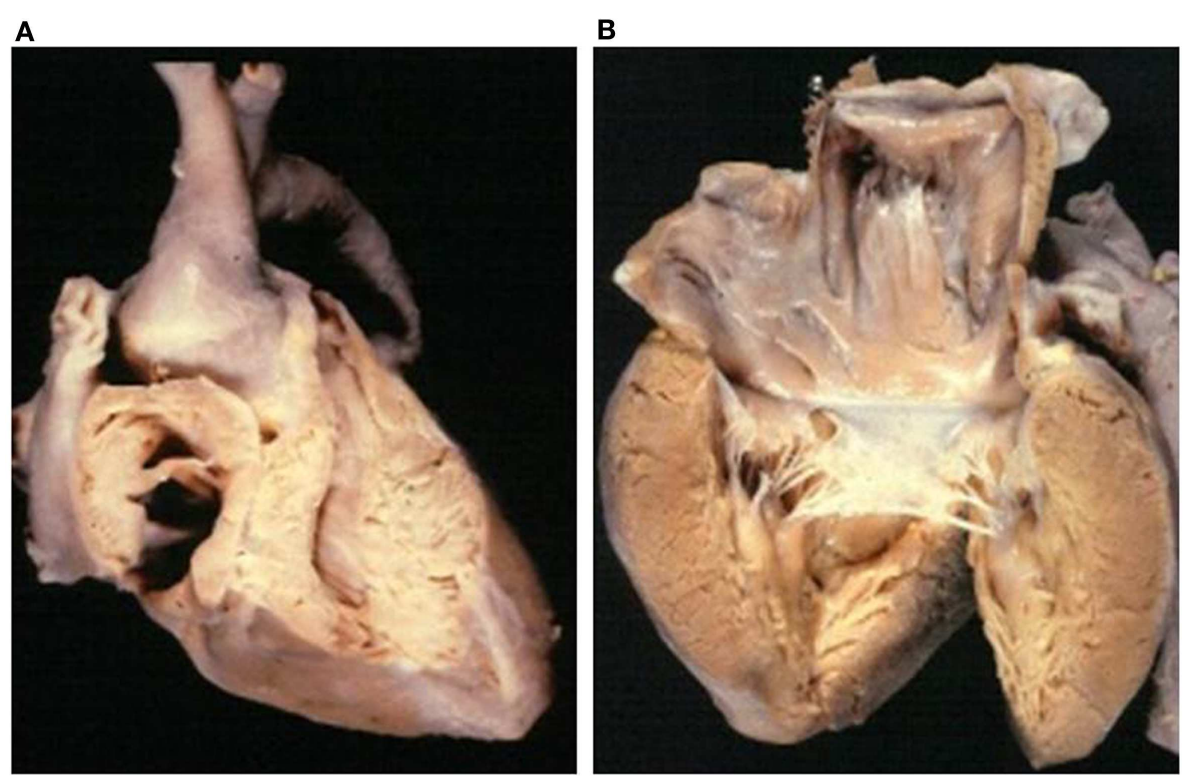

FIGURE 9 | Absent right AV connection (tricuspid atresia) with concordant VA connection. (A) There is no connection between the right atrium and the underlying right ventricle. The diminutive right ventricle is located interiorly and on the right (D-loop) lacks of an inlet portion and gives origin to a hypoplastic pulmonary artery. The two ventricles communicate through a ventricular septal defect. (B) The left atrium drains through a mitral valve into the left ventricle.
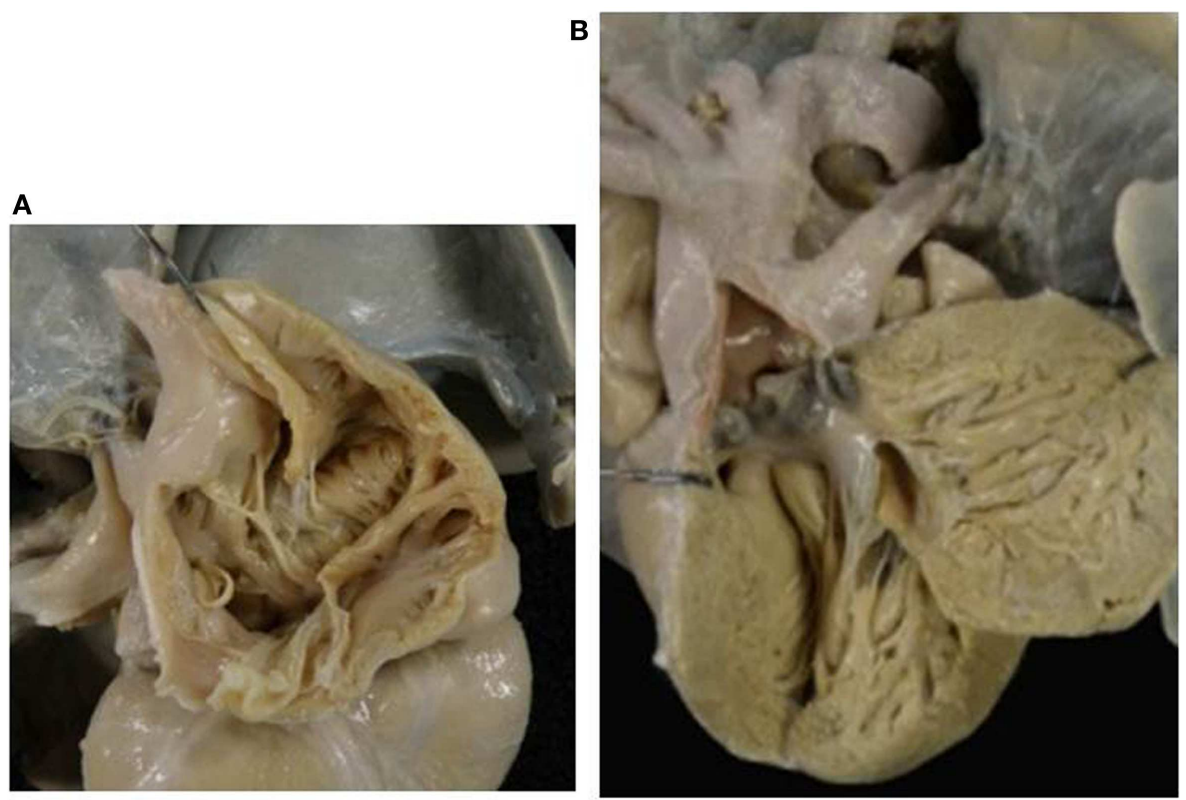

FIGURE 10 | Absent left AV valve (tricuspid atresia) with truncus arteriosus. (A) There is no orifice in the floor of the right atrium. (B) A common arterial trunk arises from the heart, prevalently from the left ventricle, and gives origin to both systemic and pulmonary circulations. Note the dysplastic, tricuspid truncal valve.

Dextrocardia was present and the hypoplastic left ventricle was located anterior and on the right (L-ventricular loop). Heterotaxy of abdominal viscera and multiple spleens were present.

Other associated anomalies are described in Table 7.

\section{HEARTS WITH BIVENTRICULAR AV CONNECTION AND SINGLE VA CONNECTION}

In our Anatomical Collection, 66 hearts were found with aortic atresia (single pulmonary outlet) with IVS (Figure 12A) and 58 with pulmonary atresia with IVS (single aortic outlet) 


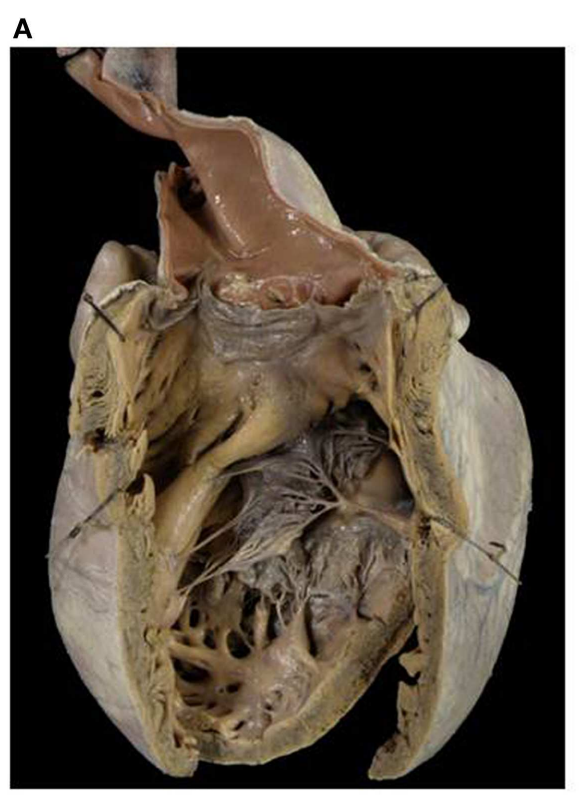

FIGURE 11 | Absent right atrioventricular connection in L-loop with single aortic outlet (pulmonary atresia). (A) A morphological

tricuspid valve joins the left atrium with a main ventricular chamber of right morphology (L-loop), from which the aorta takes origin. The

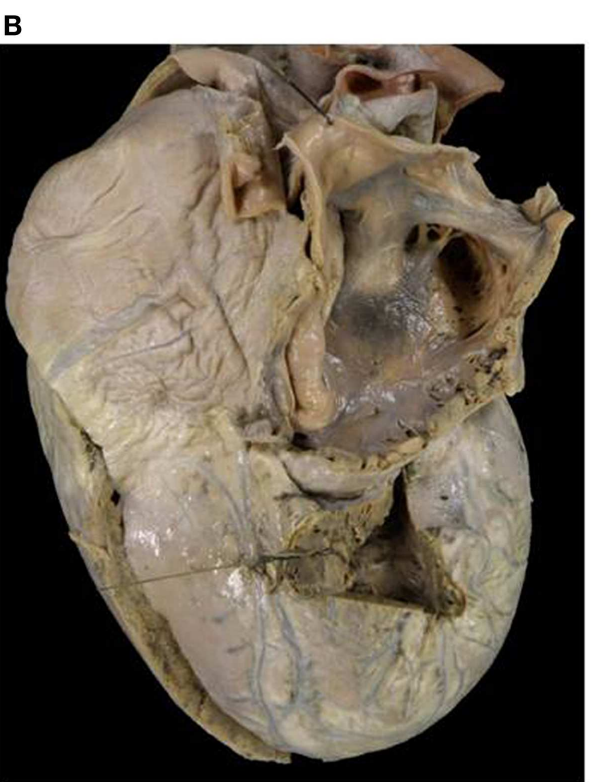

pulmonary valve is atretic (single aortic outlet). (B) At the floor of the right atrium there is no orifice. The underlying ventricular chamber is hypoplastic, posterior, right-sided and of left ventricular morphology (L-loop).

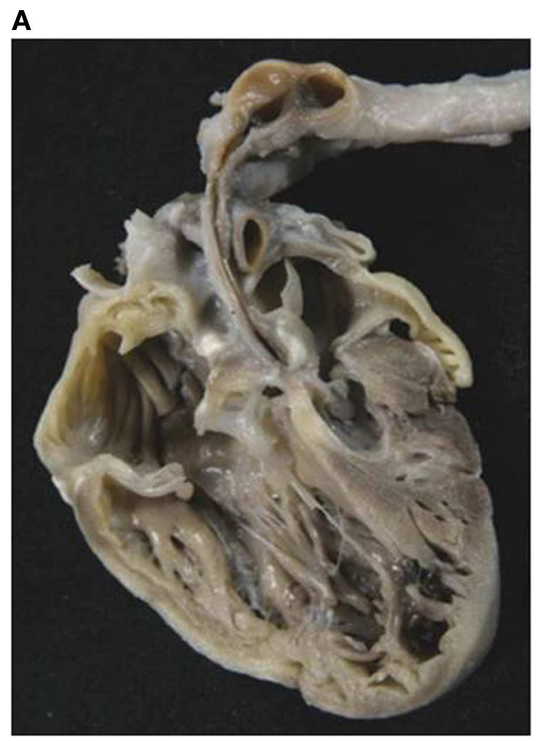

FIGURE 12 | Single outlet ventriculo-arterial connections with functionally univentricular heart. (A) Aortic atresia with intact ventricular septum (single pulmonary outlet). Four chamber echocardiographic cut of the heart showing the severe hypoplasia of the left cardiac chambers. Note the tiny inlet portion of the left
B

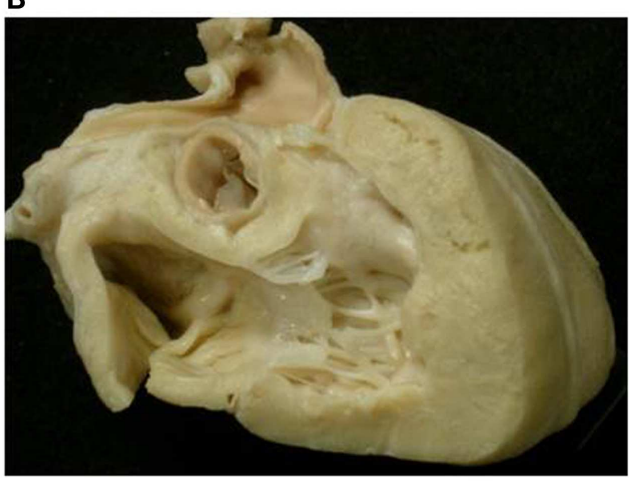

ventricle. This heart is only suitable for Norwood univentricular repair. (B) Pulmonary atresia with intact ventricular septum (single aortic outlet) with hypoplastic right ventricle. The size of the right ventricle is such that this heart may be suitable for one and half ventricle repair. 
Table 8 | Hearts with biventricular AV connection and single VA connection: mode of VA connection.

\begin{tabular}{lccc}
\hline $\begin{array}{l}\text { Mode of VA } \\
\text { connection }\end{array}$ & $\begin{array}{c}\text { Aortic atresia + IVS } \\
\text { (single pulmonary outlet) } \\
\mathbf{6 6} \text { hearts }\end{array}$ & $\begin{array}{c}\text { Pulmonary atresia + IVS } \\
\text { (single aortic outlet) } \\
\mathbf{5 8} \text { hearts }\end{array}$ \\
\cline { 2 - 4 } & - & $\begin{array}{c}\text { Hypoplastic } \\
\text { RV 51 }\end{array}$ & $\begin{array}{c}\text { Dilated } \\
\text { RV 7 }\end{array}$ \\
\hline $\begin{array}{l}\text { Absent } \\
\text { pulmonary valve }\end{array}$ & 25 & 4 \\
$\begin{array}{l}\text { Imperforate } \\
\text { pulmonary valve }\end{array}$ & - & 26 & 3 \\
$\begin{array}{l}\text { Absent aortic } \\
\text { valve }\end{array}$ & & & - \\
$\begin{array}{l}\text { Imperforate } \\
\text { aortic valve }\end{array}$ & 61 & - & - \\
\hline
\end{tabular}

$A V$, atrioventricular; IVS, intact ventricular septum; $R V$, right ventricle; VA, ventriculo-arterial.

(Figure 12B) (Table 8). Hearts with pulmonary atresia with VSD (tetralogy of Fallot with pulmonary atresia) (69 cases) and hearts with aortic atresia with VSD ( 9 cases) were excluded because they usually exhibit ventricles of good size.

All cases with pulmonary or aortic atresia occurred in situs solitus and concordant AV connections.

\section{AORTIC ATRESIA (SINGLE PULMONARY OUTLET)}

In all the 66 hearts with aortic atresia with IVS, there was levocardia, D-loop topology of the ventricles with the hypoplastic left ventricle situated posterior and on the left (Figure 12A).

The aortic valve was absent in 61 cases and imperforate in 5 (Table 8).

The left ventricle was hypoplastic in all with fibroelastosis in 22 cases.

Associated anomalies are reported in Table 9.

\section{PULMONARY ATRESIA (SINGLE AORTIC OUTLET)}

Fifty-eight hearts presented with pulmonary atresia with IVS. In all hearts, levocardia and D-loop were present.

Two different morphologic groups were found: one characterized by hypoplastic and hypertrophic right ventricle (Figures 12B, and 13) and one with dilated and functionally deficient right ventricle (Table 8).

\section{HEART WITH HYPOPLASTIC RIGHT VENTRICLE: 51 CASES}

Among the 51 hearts with hypoplastic right ventricle (Tables 8 and 9), 14 cases presented all the ventricular components; in 12 the trabecular component was absent due to muscular hypertrophy; and in 23 cases both trabecular and outlet portions were not seen because of muscular hypertrophy.

The pulmonary orifice was absent (single aortic outlet) in 25 cases and an imperforated pulmonary valve (concordant VA connection) was present in 26 cases (Table 8).
Table 9 | Hearts with biventricular AV connection and single VA connection: associated anomalies.

\begin{tabular}{|c|c|c|c|}
\hline \multirow[t]{2}{*}{$\begin{array}{l}\text { Associated } \\
\text { anomalies }\end{array}$} & \multirow[t]{2}{*}{$\begin{array}{c}\text { Aortic atresia + IVS } \\
\text { (single pulmonary outlet) } \\
66 \text { hearts }\end{array}$} & \multicolumn{2}{|c|}{$\begin{array}{l}\text { Pulmonary atresia + } \\
\text { IVS (single aortic } \\
\text { outlet) } 58 \text { hearts }\end{array}$} \\
\hline & & $\begin{array}{l}\text { Hypoplastic } \\
\text { RV } 51\end{array}$ & $\begin{array}{c}\text { Dilated } \\
\text { RV } 7\end{array}$ \\
\hline $\begin{array}{l}\text { Persistent LSVC } \\
\text { to coronary sinus }\end{array}$ & 2 & - & - \\
\hline $\begin{array}{l}\text { Anomalous Po } \\
\text { drainage into } \\
\text { RSVC }\end{array}$ & 1 & - & - \\
\hline $\begin{array}{l}\text { Intact atrial } \\
\text { septum }\end{array}$ & 2 & - & - \\
\hline ASD/PFO & $24 / 37$ & $22 / 29$ & $7 /-$ \\
\hline $\begin{array}{l}\text { Hypoplastic mitral } \\
\text { valve }\end{array}$ & 66 & - & - \\
\hline $\begin{array}{l}\text { Mitral valve } \\
\text { arcade }\end{array}$ & 2 & 1 & - \\
\hline $\begin{array}{l}\text { Dysplastic mitral } \\
\text { valve }\end{array}$ & 3 & - & - \\
\hline $\begin{array}{l}\text { Hypoplastic } \\
\text { tricuspid valve }\end{array}$ & - & 30 & - \\
\hline $\begin{array}{l}\text { Dysplastic } \\
\text { tricuspid valve }\end{array}$ & - & 16 & - \\
\hline $\begin{array}{l}\text { Ebstein tricuspid } \\
\text { valve }\end{array}$ & - & 6 & 7 \\
\hline LV fibroelastosis & 22 & - & - \\
\hline RV fibroelastosis & - & 16 & - \\
\hline Bicuspid Po valve & 1 & - & - \\
\hline Right aortic arch & - & 1 & - \\
\hline $\begin{array}{l}\text { Aortic arch } \\
\text { coarctation }\end{array}$ & 10 & - & - \\
\hline $\begin{array}{l}\text { Retro esophageal } \\
\text { subclavian artery }\end{array}$ & 1 & - & - \\
\hline $\begin{array}{l}\text { Single coronary } \\
\text { artery }\end{array}$ & - & 1 & - \\
\hline $\begin{array}{l}\text { Ductus } \\
\text { dependent Po } \\
\text { circulation }\end{array}$ & - & 51 & 7 \\
\hline
\end{tabular}

$A S D$, atrial septal defect; $L V$, left ventricle; $A V$, atrioventricular; $P F O$, patent foramen ovalis; IVS, intact ventricular septum; LSVC, left superior vena cava, RSVC, right superior vena cava $V A$, ventriculo-arterial; $P O$, pulmonary; $R V$, right ventricle.

The tricuspid valve was hypoplastic (Figures 12B and 13) in 30, dysplastic in 16 cases, and exhibited Ebstein malformation in 6.

Right ventricular fibroelastosis was noted in 16 hearts (Figure 13) and ventriculo-coronary artery connections in 10. Other associated anomalies are reported in Table 9. 


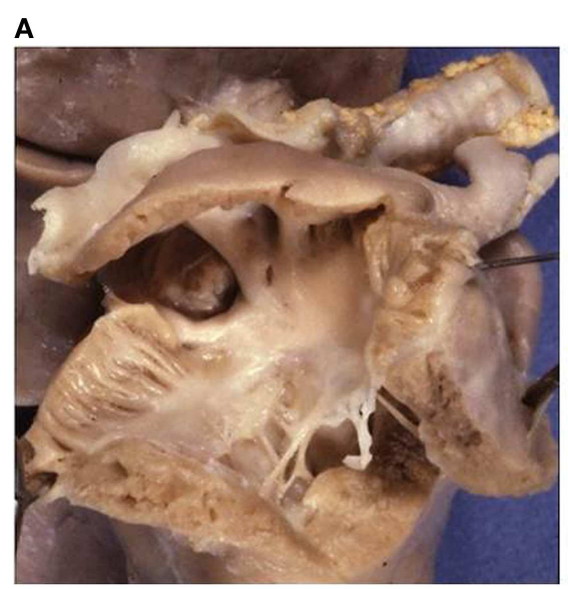

FIGURE 13 | Pulmonary atresia with intact ventricular septum (single aortic outlet). (A) View from the right cardiac chambers: the right ventricle is hypoplastic and hypertrophic. (B) View of the outflow

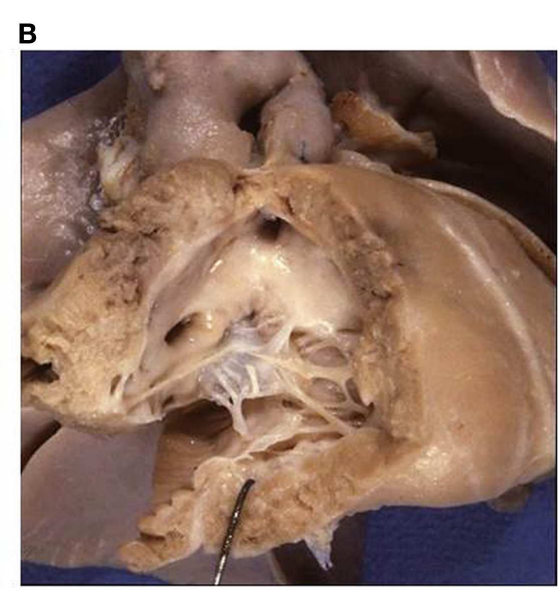

of the same case: note the endocardial fibroelastosis of the diminutive right ventricle. This heart may be suitable for one and half ventricle repair.

\section{HEARTS WITH DILATED RIGHT VENTRICLE: SEVEN CASES}

All the seven hearts presented with extremely dilated right ventricle with thin parietal wall.

The pulmonary valve was absent in four and imperforate in three hearts (Table 8).

An Ebstein anomaly of the tricuspid valve was present in all cases.

Associated anomalies are reported in Table 9.

\section{DISCUSSION}

In the past, the normal ventricles were described to possess a sinus (inlet) and conus (outlet) $(19,20)$. Subsequently, they were considered to consist of three components: inlet, apical-trabecular, and outlet (21). The tripartite approach to the ventricular analysis and the morphological features of the apical-trabecular component of the interventricular septum nowadays permit to recognize right and left ventricular morphology also in hearts with abnormal AV connection.

The left ventricle is recognizable by its fine septal apicaltrabecular trabeculations and the right ventricle by the coarse apical-trabecular aspect $(11,22)$. These anatomical characteristic are recognizable also in hearts that lack of inlet or outlet portions. The exception is the rare condition of a solitary or indeterminate ventricle in which there are no septal remnants and the apical component is uniformly coarse.

For long time, there was no agreement in considering as a true ventricle the ventricular chamber that lacks one component (23). Double inlet connection was named single ventricle despite, the fact that the heart possesses two ventricular chambers, one large and one small missing the inlet portion. The same consideration was applied to hearts showing tricuspid or mitral atresia $(2,23)$.

The hearts characterized by one large and one hypoplastic ventricular chamber are known with different terms such as: cor triloculare biatriatum (24-28), single or common ventricle (2, 19, 20, 29-34), primitive ventricle (35-37), double inlet ventricle (38-41), and univentricular heart (42-51).
All these definitions pointed the attention to the ventricular mass, identifying the morphology of the dominant ventricular chamber.

Afterward, the attention was focused not only to the ventricles but also to the AV connection and these hearts were regarded as having a univentricular $A V$ connection (52-54). This term represents a common denomination for all the hearts in which both the atria, directly or indirectly, connect predominantly to only one ventricle. This fact does not exclude the presence of two ventricles, even if one is hypoplastic or incomplete. In this way, the concept of univentricular $\mathrm{AV}$ connection groups hearts with double inlet connection and hearts with absent right or left AV connection.

Recently, the term functionally univentricular hearts was introduced (14-18) to identify not only hearts with univentricular AV connection (absent right or left AV connection, double inlet left, right, or indeterminate ventricle), but also hearts with biventricular AV connection (each atrium connects separately with its own ventricle), in which the right or left ventricles are too small as to be unable to sustain the pulmonary or the systemic circulation, respectively, if a biventricular surgical repair is accomplished.

Even if a ventricle possesses all components, it does not mean that it will be always of size enough to bear a normal function. In pulmonary atresia with IVS, the right ventricle possesses all components but the ventricular cavity may be quite diminutive due to the extreme hypertrophy of the wall (55) (Figure 12B) or in some cases, with Ebstein anomaly of the tricuspid valve and large atrialization of a ventricular portion, the remaining right ventricle is functionally inadequate and unable to sustain a biventricular repair (Figure 14).

The surgical repair in functional univentricular hearts varies according to the morphology and the potential function of the hypoplastic ventricles. In some cases, with good sized ventricles, a biventricular correction can be performed, while in others the small ventricle can be suitable for a one and half ventricle repair. If one of the ventricle is severely hypoplastic or dysfunctional, only a univentricular repair can be considered. 

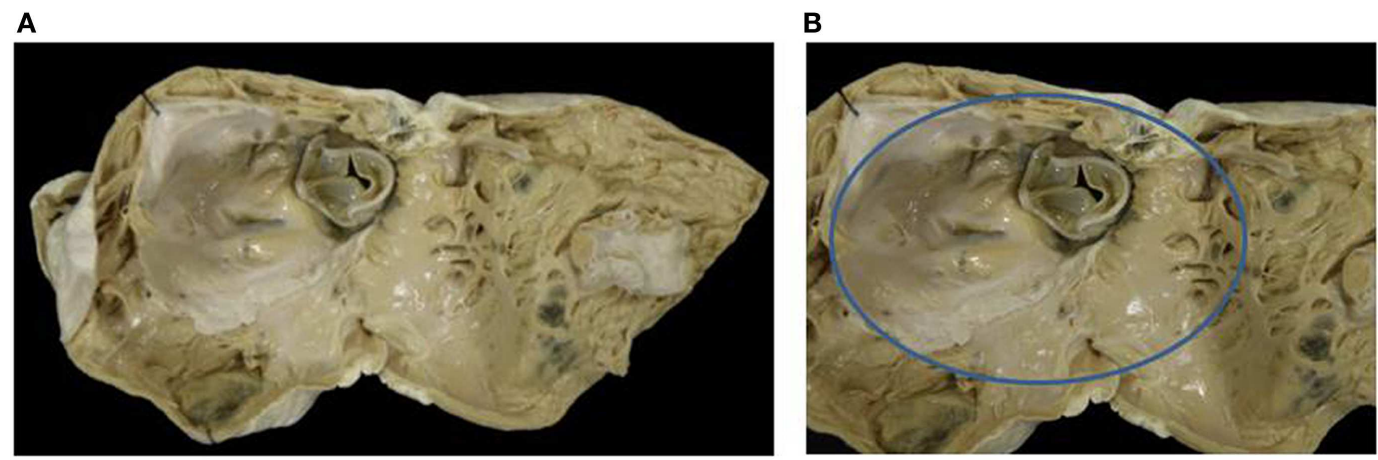

FIGURE 14 | Ebstein anomaly of the tricuspid valve. (A) View from the apex of the right ventricle. A prosthetic valve was inserted ad the AV annulus. A large atrialized area is situated between the AV annulus and the displaced leaflets of the tricuspid valve. Note the thin wall of the right ventricle. In this patient, heart transplantation was performed because the dilated right ventricle was unable to sustain the pulmonary circulation. (B) Close up of the same specimen showing the atrialized area.
Double inlet left ventricle with D-loop and concordant VA connection is a rare situation, known as Holmes heart $(56,57)$ (Figure 4). The most frequent VA connection is the discordant one (Figure 3). In these cases, the VSD (also known as bulboventricular foramen) may be small and obstructive, accounting for subaortic stenosis in half of cases. Somebody avoid the use of the term bulbo-ventricular foramen in double inlet ventricle and suggest to describe the communication between the ventricular chambers simply as VSD $(58,59)$. The ascending aorta is hypoplastic compared with the dilated pulmonary artery and obstruction of the aortic arch, in the shape of coarctation, interruption or atresia, can be observed (Figure 3). In rare occasion, both great vessels may originate from the dominant left ventricle or from the hypoplastic right ventricle (double outlet left or right ventricle).

Double inlet right ventricle shows a dominant ventricle of right morphology with coarse apical trabeculations and a second hypoplastic ventricular chamber of left morphology located in postero-inferior position, usually on the left and rarely on the right, according to the ventricular loop.

In these cases right isomerism is frequently present and associated with a common $\mathrm{AV}$ valve as the mode of $\mathrm{AV}$ connection and double outlet right ventricle is the commonest VA connection (43, 49, 50). Any type of VA connection may occur: single aortic outlet (pulmonary atresia), concordant VA, and more rarely discordant VA connection.

In cases with right isomerism, the presence of common atrium, anomalous pulmonary venous drainage, and visceral heterotaxy can complicate the clinical presentation.

The description of the side of the absent connection (right or left), associated with the identification of the septal position of the ventricle ( $\mathrm{D}$ - or L-loop) are to be preferred to the nomination of the malfomation as tricuspid in mitral atresia (60-62). In fact, in hearts with absent right AV connection and $\mathrm{D}$-loop, the patent left $\mathrm{AV}$ valve is a mitral valve, but in case of L-loop, the patent left AV valve is a tricuspid valve (Figure 11).

Absent right $A V$ connection (60) and D-loop is usually associated to concordant VA connection and the size of the right ventricle and pulmonary trunk depends on the dimension of the VSD. In some cases, the VA connection is discordant (transposition of the great arteries) and obstruction of the aortic arch can be present, if the VSD is restrictive. Dextrocardia and juxtaposition of the atrial appendages can be observed (63).

The majority of cases with absent left AV connection (60) is associated with single pulmonary outlet (aortic atresia). In these cases, the left ventricle is virtual. The rare presence of a VSD does not change the clinical presentation and double outlet right ventricle or discordant VA connections are found. Fibroelastosis of the left ventricle is not observed in absent left AV connection.

Hypoplastic left ventricle is associated to isolated aortic atresia with IVS. In these cases, the mitral valve is patent, but hypoplastic so that a tiny portion of the left ventricle is present, and fibroelastosis of the left heart is usually associated (Figure 12A).

Also some cases with critical aortic stenosis may be associated with hypoplastic left ventricle and endocardial fibroelastosis (Figure 15). The patency of mitral or aortic valve does not change the physiology of the hypoplastic left heart, even though all its components are present. This is classical situation in which a one and half ventricle repair may be considered.

Also the right ventricle can be hypoplastic, not only in the setting of an absent right $\mathrm{AV}$ connection or double inlet left ventricle, but as consequence of pulmonary atresia or critical pulmonary stenosis with IVS. In cases with pulmonary atresia with IVS, the size of right ventricular cavity is quite reduced due to severe muscular hypertrophy of the free ventricular wall (Figure 12B) (55) and also the association with endocardial fibroelastosis (Figure 13) can jeopardize the ventricular contractility.

When pulmonary atresia is associated to VSD (Tetralogy of Fallot with pulmonary atresia) or aortic atresia is associated to VSD right and left ventricular cavities maintain a good size and biventricular repair can be performed.

In Ebstein anomaly, isolated or in association with pulmonary atresia with IVS (64), the extreme atrialization of the right ventricle is such that the residual ventricle is unable to sustain the pulmonary circulation if biventricular repair is accomplished, because 

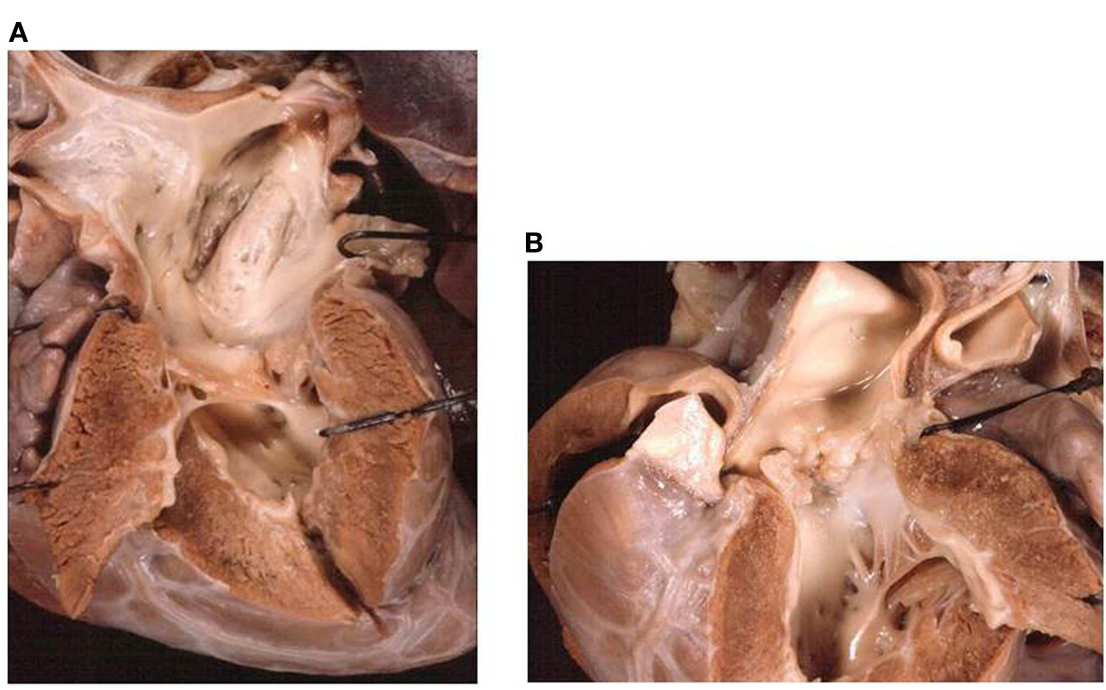

FIGURE 15 | Aortic stenosis with hypoplastic left heart. (A) View from the left ventricular chambers: the left ventricle is hypoplastic with hypertrophic free wall. Note the hypoplastic mitral valve and the severe endocardial fibroelastosis of the left ventricle. (B) A severe aortic stenosis is present with dysplastic aortic valve. This heart may be amenable for one and half ventricle repair. the download displacement of septal and posterior leaflets of the tricuspid valve reduces the ventricle to apical and outlet portions (Figure 14).

In conclusion, the term functionally univentricular heart encompasses not only hearts known as single or common ventricle or univentricular heart, where one dominant and one hypoplastic chamber are present, and in which one ventricle lacks inlet component (double inlet or absent AV connection), but also hearts in which both ventricles possess all the morphological components but where one ventricle is tiny and unable to sustain the circulation.

The use of this definition, based not only on the morphology of the ventricles but also on their function, is relevant in planning biventricular, univentricular, or one and half ventricle surgical repairs (65-67).

\section{REFERENCES}

1. De la Cruz MV, Berrazueta JR, Arteaga M, Attie F, Soni J. Rules for diagnosis of arterioventricular discordances and spatial identification of ventricles. Br Heart $J$ (1967) 38:341-54. doi:10.1136/hrt.38.4.341

2. Van Praagh R, Ongley PA, Swan HJC. Anatomic types of single and common ventricle in man. Morphologic and geometric aspects of sixty necropsied cases. Am J Cardiol (1964) 13:367-86. doi:10.1016/0002-9149(64)90453-9

3. Van Praagh R, Van Praagh S, Vlad P, Keith JD. Anatomical types of congenital dextrocardia. Diagnosis and embryologic implications. Am J Cardiol (1964) 13:315-35. doi:10.1016/0002-9149(64)90159-6

4. Van Praagh R. The segmental approach to diagnosis in congenital heart disease. Birth Defects, Original Article Series 8. Baltimore: Williams and Wilkins (1972). p. 4-23.

5. Macartney FJ, Shinebourne EA, Anderson RH. Connexions, relations, discordance and distortions. Br Heart J (1976) 38:323-6. doi:10.1136/hrt.38.4.323

6. Shinebourne EA, Macartney FJ, Anderson RH. Sequential chamber localization: logical approach to diagnosis in congenital heart disease. Br Heart J (1976) 38:327-40. doi:10.1136/hrt.38.4.327

7. Tynan MJ, Becker AE, Macartney FJ, Quero-Jimenez M, Shinebourne EA, Anderson RH. Nomenclature and classification of congenital heart disease. Br Heart J (1979) 41:544-53. doi:10.1136/hrt.41.5.544
8. Anderson RH, Becker AE, Freedom RM, Macartney FJ, Quero-Jimenez M, Shinebourne EA, et al. Sequential segmental analysis of congenital heart disease. Pediatr Cardiol (1984) 5:281-8. doi:10.1007/BF02424973

9. Anderson RH. Simplifying the understanding of congenital malformations of the heart. Int J Cardiol (1991) 32:131-42. doi:10.1016/0167-5273(91) 90322-G

10. Anderson RH, Ho SY. Sequential segmental analysis: description and categorization for the millennium. Cardiol Young (1997) 7:98-116. doi:10.1017/ S1047951100005953

11. Anderson RH, Shirali G. Sequential segmental analysis. Ann Pediatr Cardiol (2009) 2:24-35. doi:10.4103/0974-2069.52803

12. Thiene G, Frescura C. Anatomical and pathophysiological classification of congenital heart disease. Cardiovasc Pathol (2010) 19:259-74. doi:10.1016/j.carpath. 2010.02.006

13. Frescura C, Valsangiacomo Buchel E, Ho SY, Thiene G. Anatomical and patho-physiological classification of congenital heart disease. In: Saremi F, Achenbach S, Arbustini E, Narula J, editors. Revisiting Cardiac Anatomy. A Computed-Tomography-Bases Atlas and Reference. Blackwell: Wiley (2011). p. $40-75$.

14. Anderson RH, Cook AC. Morphology of the functional univentricular heart. Cardiol Young (2004) 14(Suppl 1):3-12. doi:10.1017/S1047951104006237

15. Cook AC, Anderson RH. The functionally univentricular circulation: anatomic substrates as related to function. Cardiol Young (2005) 15(Suppl 3):7-16 doi:10.1017/S1047951105001563

16. Jacobs ML, Anderson RH. Nomenclature of the functionally univentricular heart. Cardiol Young (2006) 16(Suppl 1):3-8. doi:10.1017/ S104795110500226X

17. Jacobs JP, Franklin RC, Jacobs ML, Colan SD, Tchervenkov CI, Maruszewski $\mathrm{B}$, et al. Classification of the functionally univentricular heart: unity from mapped codes. Cardiol Young (2006) 16(Suppl 1):9-21. doi:10.1017/ S1047951105002271

18. Mahle WT, Silverman NH, Marx GR, Anderson RH. Echo-morphological correlates concerning the functionally univentricular heart in the setting of isomeric atrial appendages. Cardiol Young (2006) 16(Suppl 1):35-42. doi:10.1017/ S1047951105002301

19. Lev M, Liberthson RR, Kirkpatrick JR, Eckner FAO, Arcilla RA. Single (primitive) ventricle. Circulation (1969) 39:577-91. doi:10.1161/01.CIR.39.5.577

20. Van Praagh R, Plett JA, Van Praagh S. Single ventricle. Pathology embryology, terminology and classification. Herz (1979) 4:113-50.

21. Goor DA, Lillehei CW. Congenital Malformations of the Hearts. New York, NY: Grune and Stratton (1975). p. 1-37. 
22. Anderson RH, Mohun TJ, Moorman AF. What is a ventricle? Cardiol Young (2011) 21 (Suppl 2):14-22. doi:10.1017/S1047951111001387

23. Van Praagh R, David I, Wraight GB, Van Praagh S. Large RV plus small LV is not a single ventricle. Circulation (1980) 621:1057-8.

24. Mann D. Cor triloculare biatriatum. Br Med J (1907) 1:614-8. doi:10.1136/bmj. 1.2411 .614

25. Brodie J. Cor biatriatum triloculare with transposition of the arterial trunks: rare congenital cardiac malformations. J Pathol Bacteriol (1945) 31:481-5. doi:10.1002/path.1700570412

26. Rogers HM, Edwards JE. Cor triloculare biatriatum. An analysis of the clinical and pathological features of nine cases. Am Heart J (1951) 41:299-310. doi:10.1016/0002-8703(51)90108-1

27. Heath D. Cor triloculare bitriatum. Circulation (1957) 15:701-12. doi:10.1161/ 01.CIR.15.5.701

28. Rosenquist G, Olney M, Roe BA. The Holmes heart, a variant of cor triloculare biatriatum. Circulation (1963) 28:1143-7. doi:10.1161/01.CIR.27.6.1143

29. Taussig HB. A single ventricle with diminutive outlet chamber. J Tech Methods (1939) 19:120-8.

30. Quero M. Coexistence of single ventricle with atresia of one atrioventricular orifice. Circulation (1972) 46:794-8. doi:10.1161/01.CIR.46.4.794

31. Somerville J, Becu L, Ross DN. Common (single) ventricle with acquired subaortic obstruction. Am J Cardiol (1974) 34:206-14. doi:10.1016/0002-9149(74) 90199-4

32. Marin-Garcia J, Tandon R, Moller JH, Edwards JE. Common (single) ventricle with normally related great arteries. Circulation (1974) 49:565-73. doi:10.1161/ 01.CIR.49.3.565

33. Macartney FJ, Partridge JB, Scott O, Deverall PB. Common or single ventricle. An angiographic and hemodynamic study of 43 patients. Circulation (1976) 53:543-54. doi:10.1161/01.CIR.53.3.543

34. Van Praagh R, Plett JA, Van Praagh S. Single ventricle. Hertz (1979) 4:113-50.

35. Liberthson RR, Paul MH, Muster AJ, Arcilla RA, Eckner FA, Lev M. Straddling and displaced atrioventricular orifices and valves with primitive ventricles. Circulation (1974) 43:213-26. doi:10.1161/01.CIR.43.2.213

36. Somerville J, Ross DN, Yacub M, Radley-Smith R. Primitive ventricle with acquired subpulmonary stenosis. Eur J Cardiol (1975) 3:193-203.

37. Otero-Coto E, Caffarena Raggio JM, Malo P, Sainz C, Aparisi R. Single primitive ventricle with normally related great arteries and atresia of the left $\mathrm{AV}$ valve. Thorax (1978) 33:616-24.

38. De La Cruz MV, Miller LB. Double inlet left ventricle: two pathological specimens with comments on embryology and on its relation to single ventricle. Circulation (1968) 37:249-60. doi:10.1161/01.CIR.37.2.249

39. Tandon R, Becker AE, Moller JH, Edwards JE. Double inlet left ventricle Straddling tricuspid valve. Br Heart J (1974) 36:747-59. doi:10.1136/hrt.36.8. 747

40. Freedom RM, Nanton M, Dishe MR. Isolated ventricular inversion in double inlet left ventricle. Eur J Cardiol (1977) 5:63-86.

41. Keeton BR, Macartney FJ, Rees PG, Hunter S, Shinebourne EA, Tynan MJ, et al. Double inlet right ventricle. Br Heart J (1977) 39:930-5.

42. Anderson RH, Becker AE, Wilkinson JL, Gerlis LM. Morphogenesis of univentricular hearts. Br Heart J (1976) 38:558-72. doi:10.1136/hrt.38.6.558

43. Soto B, Bertranou EG, Bream PR, Souza A Jr, Bargeron LM Jr. Angiography of univentricular heart of right ventricular type. Circulation (1977) 60:125-34.

44. McGoon DC, Kanielson GK, Ritter DG, Wallace RB, Maloney JD, Marcelletti C. Correction of univentricular heart having two atrioventricular valves. $J$ Thorac Cardiovasc Surg (1977) 74:218-26.

45. Keeton BR, Macartney FJ, Hunter S, Mortera C, Rees P, Shinebourne EA, et al. Univentricular heart of right ventricular type with double or common inlet. Circulation (1979) 59:403-11. doi:10.1161/01.CIR.59.2.403

46. Anderson RH, Becker AE, Freedom RM, Quero-Jiménez M, Macartney FJ, Shinebourne EA, et al. Problems in the nomenclature of the univentricular heart. Herz (1979) 4:97-106.

47. Wilkinson JL, Becker AE, Tynan M, Freedom R, Macartney FJ, Shinebourne EA, et al. Nomenclature of the univentricular heart. Herz (1979) 4:107-12.

48. Anderson RH, Tynan M, Freedom RM, Quero-Jiménez M, Macartney FJ, Shinebourne EA, et al. Ventricular morphology in the univentricular heart. Herz (1979) 4:184-97.
49. Shinebourne EA, Lau KC, Calcaterra G, Anderson RH. Univentricular heart of right ventricular type: clinical, angiographic and echocardiographic features. Am J Cardiol (1980) 46:439-45. doi:10.1016/0002-9149(80)90013-2

50. Rigby ML, Anderson RH, Gibson D, Jones OD, Joseph MC, Shinebourne EA. Two dimensional echocardiographic categorization of the univentricular heart. Ventricular morphology, type, and mode of atrioventricular connection. $\mathrm{Br}$ Heart J (1981) 46:603-12. doi:10.1136/hrt.46.6.603

51. Anderson RH. Univentricular hearts. Am J Cardiol (1984) 54:941-2. doi:10. 1016/S0002-9149(84)80271-4

52. Anderson RH, MaCartney FJ, Tynan M, Becker AE, Freedom RM, Godman MJ, et al. Univentricular atrioventricular connection: the single ventricle trap unsprung. Pediatr Cardiol (1983) 4:273-80. doi:10.1007/BF02278873

53. Anderson RH, Becker AE, Tynan M, Macartney FJ, Rigby LM, Wilkinson JL. The univentricular atrioventricular connection: getting to the root of a thorny problem. Am J Cardiol (1984) 54:822-8. doi:10.1016/S0002-9149(84) 80214-3

54. Ho SY, Zuberbuhler JR, Anderson RH. Pathology of hearts with a univentricular atrioventricular connection. Perspect Pediatr Pathol (1988) 12:69-99.

55. Anderson RH, Anderson C, Zuberbuhler JR. Further morphologic studies on hearts with pulmonary atresia and intact ventricular septum. Cardiol Young (1991) 1:105-13. doi:10.1017/S1047951100000214

56. Holmes WF. Case of malformation of the heart. Trans Med Chir Soc Edin (1824) $1: 252-4$.

57. Dobell AR, Van Praagh R. The Holmes heart: historic association and pathological anatomy. Am Heart J (1996) 132:437-45. doi:10.1016/S0002-8703(96) 90443-3

58. Anderson RH, Ho SY, Wilcox BR. The surgical anatomy of ventricular septal defects with univentricular atrioventricular connection. J Card Surg (1994) 9:408-26. doi:10.1111/j.1540-8191.1994.tb00870.x

59. Cook AC, Anderson RH. The anatomy of hearts with double inlet ventricles. Cardiol Young (2006) 16(Suppl 1):11-26. doi:10.1017/S1047951105002283

60. Anderson RH, Wilkinson JL, Gerlis LM, Smith A, Becker AE. Atresia of the right atrioventricular orifice. Br Heart J (1977) 39:414-28. doi:10.1136/hrt.39.4.414

61. Thiene G, Daliento L, Frescura C, De Tommasi M, Macartney FJ, Anderson RH. Atresia of left atrioventricular orifice. Anatomical investigation in 62 cases. $\mathrm{Br}$ Heart J (1981) 45:393-401. doi:10.1136/hrt.45.4.393

62. Martinez RM, Anderson RH. Echo morphological correlates in atrioventricular valvar atresia. Cardiol Young (2006) 16(Suppl 1):27-34. doi:10.1017/ S1047951105002295

63. Frescura C, Thiene G. Juxtaposition of the atrial appendages. Cardiovasc Pathol (2012) 21:169-79. doi:10.1016/j.carpath.2011.02.002

64. Freedom RM, Jaeggi E, Perrin D, Yoo SJ, Anderson RH. The "wall-to-wall" heart in the patient with pulmonary atresia and intact ventricular septum. Cardiol Young (2006) 16:18-29. doi:10.1017/S1047951105002040

65. Anderson RH, Ho SY. Pathologic substrates for $11 / 2$ ventricular repair. Ann Thorac Surg (1998) 66:673-7. doi:10.1016/S0003-4975(98)00575-X

66. Anderson RH, Ho SY. Which hearts are unsuitable for biventricular correction? Ann Thorac Surg (1998) 66:621-6. doi:10.1016/S0003-4975(98)00579-7

67. Freedom RM, Van Arsdell GS. Univentricular heart not amenable to biventricular repair. Ann Thorac Surg (1998) 66:641-3. doi:10.1016/S0003-4975(98) 00620-1

Conflict of Interest Statement: The authors declare that the research was conducted in the absence of any commercial or financial relationships that could be construed as a potential conflict of interest.

Received: 16 April 2014; accepted: 30 May 2014; published online: 07 July 2014. Citation: Frescura $C$ and Thiene $G$ (2014) The new concept of univentricular heart. Front. Pediatr. 2:62. doi: 10.3389/fped.2014.00062

This article was submitted to Pediatric Cardiology, a section of the journal Frontiers in Pediatrics.

Copyright $(2014$ Frescura and Thiene. This is an open-access article distributed under the terms of the Creative Commons Attribution License (CC BY). The use, distribution or reproduction in other forums is permitted, provided the original author(s) or licensor are credited and that the original publication in this journal is cited, in accordance with accepted academic practice. No use, distribution or reproduction is permitted which does not comply with these terms. 